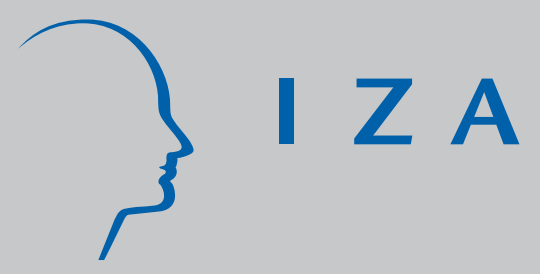

IZADP No. 1914

CEO Turnover, Firm Performance and Enterprise Reform in China: Evidence from New Micro Data

Takao Kato

Cheryl Long

J anuary 2006 


\title{
CEO Turnover, Firm Performance and Enterprise Reform in China: Evidence from New Micro Data
}

\author{
Takao Kato \\ Colgate University, Columbia University \\ and IZA Bonn \\ Cheryl Long \\ Colgate University, Stanford University \\ and University of Electronic Science and Technology of China
}

Discussion Paper No. 1914

January 2006

\author{
IZA \\ P.O. Box 7240 \\ 53072 Bonn \\ Germany \\ Phone: +49-228-3894-0 \\ Fax: +49-228-3894-180 \\ Email: iza@iza.org
}

\begin{abstract}
Any opinions expressed here are those of the author(s) and not those of the institute. Research disseminated by IZA may include views on policy, but the institute itself takes no institutional policy positions.
\end{abstract}

The Institute for the Study of Labor (IZA) in Bonn is a local and virtual international research center and a place of communication between science, politics and business. IZA is an independent nonprofit company supported by Deutsche Post World Net. The center is associated with the University of Bonn and offers a stimulating research environment through its research networks, research support, and visitors and doctoral programs. IZA engages in (i) original and internationally competitive research in all fields of labor economics, (ii) development of policy concepts, and (iii) dissemination of research results and concepts to the interested public.

IZA Discussion Papers often represent preliminary work and are circulated to encourage discussion. Citation of such a paper should account for its provisional character. A revised version may be available directly from the author. 


\title{
ABSTRACT \\ CEO Turnover, Firm Performance and Enterprise Reform in China: Evidence from New Micro Data*
}

\begin{abstract}
Using comprehensive financial and accounting data on China's listed firms from 1998 to 2002, augmented by unique data on CEO turnover, ownership structure and board characteristics, we estimate Logit models of CEO turnover. We find consistently for all performance measures including both stock return and various accounting measures that: (i) overall, CEO turnover is significantly and inversely related to firm performance though the magnitude of the relationship is modest; (ii) CEO turnover-performance link is stronger when the percentage of company shares owned by the largest shareholder is larger. Furthermore, insofar as stock performance is concerned, (iii) turnover-performance link is found to be weaker for listed firms still controlled by the state; (iv) the appointment of independent directors enhances turnover-performance link; (v) the listing suspension mechanism, i.e., the ST designation, adopted by China's securities regulatory agency appears to be effective in improving turnover-performance tie; and (vi) listed firms with CEOs holding additional positions in the controlling shareholders have weaker turnover-performance link. Consistent with the "law and finance" approach to corporate governance and the literature on economic transition, our findings suggest that any fundamental improvement in China's corporate governance will require a broad program that encompasses not only privatization but also laws and their effective implementation to provide better protection for investors.
\end{abstract}

JEL Classification: M52, M12, J33, P34, G30, O16, O53, G30, G15

Keywords: executive turnover, firm performance, enterprise reform, corporate governance, ownership structure, China, and transition economies

Corresponding author:

Takao Kato

Department of Economics

Colgate University

13 Oak Drive

Hamilton, NY 13346

USA

Email: tkato@mail.colgate.edu

\footnotetext{
* This research was funded by grants from the ABDI (Asian Development Bank Institute) and the Asian Studies program of Colgate University, as well as a Picker Research Fellowship from the Research Council of Colgate University. Kevin J. Murphy, Runtian Jing, and Jan Svejnar provided us with advice and encouragement on our research program on managerial incentives in China in general. The paper also benefited from comments and suggestions from participants at the Public Economic Theory Annual Meeting 2004 (Beijing), at the Economics Department seminar in Wesleyan University, and at the Department of Agricultural and Resource Economics Seminar in UC-Davis. The data used in the paper are provided by Shenzhen GuoTaiAn IT Co. and SinoFin Inc. We are grateful for support from these individuals and organizations.
} 


\section{CEO Turnover, Firm Performance, and Enterprise Reform in China: Evidence from New Micro Data}

\section{Section 1: Introduction}

Executive turnover and its link to firm performance have been the focus of a large and growing literature since they provide a crucial measure of how effective a firm solves the two sets of principal-agent problems it faces: (i) diverging interests between top management and shareholders, which may result in managerial entrenchment; and (ii) diverging interests between the controlling shareholders and the minority shareholders, which may lead to the expropriation of the latter by the former or "tunneling," as referred to in the literature. ${ }^{1}$ Specifically, tying the personal fortune of top executives to the performance of the firm aligns the interests of the shareholders and those of the management. It also breaks up the "insider" alliance between the controlling shareholder and the management and therefore helps protect the interests of outside investors (or minority shareholders). As such, executive turnover-performance sensitivities can serve as an important indicator of how well the corporate governance system functions.

In this paper, we study such link of executive turnover to firm performance in Chinese listed firms and provide the first systematic evidence on the turnover-performance sensitivities of Chinese top executives. By now a large literature has been developed on executive turnover, mostly on U.S. firms and increasingly on firms in other industrialized countries as well. ${ }^{2}$ There is, however, relatively limited evidence on developing and transitional economies. ${ }^{3}$ In particular, no turnover-performance sensitivity estimate is available for China, which is presently the largest

\footnotetext{
${ }^{1}$ See for instance Bebchuk (1999), Bebchuk, Kraakman, and Triantis (1999), Johnson et al. (2000), and Volpin (2002).

${ }^{2}$ For a review of the earlier literature on executive turnover which tends to focus on the U.S., the U.K., Japan and Germany, see Murphy (1999). For studies on other industrialized countries, see for instance Volpin (2002) and Brunello, Graziano and Parigi (2003) on Italy; Suchard, Singh and Barr (2001) on Australia; Zhou (2000) on Canada; Lausten (2002) and Neumann and Voetmann (2005) on Denmark; and Campbell and Keys (2002) on South Korea.

${ }^{3}$ Studies on other developing and transitional economies include Claessens and Djankov (1999, 2002), Muravyev (2003), Eriksson (2004), Gibson (2003), Defond and Hung (2004), and Klapper and Love (2004).
} 
transition economy in the world. ${ }^{4}$ By early 2004, China’s stock market has emerged as the eighth largest in the world with close to 1,300 listed firms and market capitalization of over \$550 billions. ${ }^{5}$ By focusing on China's listed firms, our paper therefore attempts to fill possibly the greatest gap in the large and growing literature on executive turnover.

Perhaps more importantly, China is an ideal case for a study of internal corporate governance including CEO turnover for at least two reasons. Firstly, the internal disciplinary mechanism that determines CEO turnover is particularly important due to the lack of effective markets for corporate control in China. ${ }^{6}$ In addition, both types of agency problem are acute in China due to the poorly defined property right and weak investor protection (resulting in part from the legacy of the command economy). Volpin (2002) regards Italy as an ideal case for a study of top executive turnover in the absence of strong investor protection. We argue that the Chinese case adds an important new dimension to the issue of investor protection and agency problems, i.e., the majority shareholders are often the state with a complex set of objectives. As such, a careful study of top executive turnover in Chinese listed firms will provide new insights

\footnotetext{
${ }^{4}$ There are a few previous studies on link of executive compensation to firm performance in China which focused on SOEs before the stock market era and found positive and significant link of accounting performance measures to executive compensation (Groves et al., 1995, Liu and Otsuka, 2004, and Mengistae and Xu, 2004). In addition, they demonstrated that most SOE reform measures in the 1980s and the 1990s were by and large successful in enhancing pay-performance link. Thus, Groves et al. (1995) provide evidence consistent with the view that the SOE reform measures in the 1980s including profit responsibility contracts have improved pay-performance linkage. Mengistae and Xu (2004) show that certain specific reform measures such as profit retention increase payperformance link while others including autonomy in production and sales decisions do not.

${ }^{5}$ There were 1,288 firms listed in the Shanghai and Shenzhen Stock Exchanges by the end of April in 2004. Source: Shanghai and Shenzhen Stock Exchanges. One estimate puts the market capitalization in China's stock markets at about 50\% of China's GDP, which is comparable to the ratio in Japan (See People's Daily, Feb. 22, 2001). A more conservative estimate discounting values of shares owned by the state and legal persons puts the ratio at $20 \%$.

${ }^{6}$ Some Chinese listed firms have experienced changes in their controlling shareholders. However, these changes differ substantially from corporate takeovers in the West. The three main methods of control change in China include negotiated ownership transfer paid by cash, negotiated ownership transfer through asset swaps, and ownership transfer without payment. All three methods are heavily regulated or orchestrated by the government. (For more detailed discussion on corporate control changes in China, see Cai and Chen 2004.)
} 
into how the two types of agency problems play out in a transitional economy where state control of listed firms is still paramount.

Specifically, using 1998 to 2002 financial and accounting data on China’s listed firms, augmented by unique data on CEO turnover, ownership structure and board characteristics, We find consistently for all performance measures including both stock return and various accounting measures that: (i) overall, CEO turnover is significantly (statistically) and inversely related to firm performance though the magnitude of the relationship is modest; (ii) perhaps more importantly CEO turnover-performance link is stronger when the percentage of company shares owned by the largest shareholder is larger. In addition, insofar as stock performance is concerned, (iii) the link between firm performance and CEO turnover is found to be stronger for privately-controlled listed firms than for state-controlled listed firms; (iv) the appointment of independent directors enhances the link between firm performance and CEO turnover; (v) the listing suspension mechanism, i.e., the ST designation, adopted by China's securities regulatory agency appears to be effective in improving the link between firm performance and turnover; and (vi) listed firms with CEOs who also hold positions in the controlling shareholders have weaker link of CEO turnover to performance.

Our findings appear to paint a mixed picture of China’s corporate governance. Overall, CEO turnover-performance sensitivities in China's listed firms are found to be statistically significant yet economically still unimportant. The sensitivities of CEO turnover to firm performance are especially weak for listed firms still controlled by the state and with a relatively weak controlling shareholder. However, the substantially stronger stock performance-turnover link observed in privately controlled firms suggests that a speed-up of the privatization process in China will lead to further improvement in its corporate governance, confirming the benefits from 
privatization. $^{7}$ In addition, a few specific measures adopted by the Chinese Securities Regulatory Commission (the CSRC hereafter) seem effective in strengthening the stock performance-turnover tie. Both the introduction of the ST designation and independent directors are found to boost the link between stock performance and CEO turnover. Thus to the extent that such link indicates better corporate governance, these CSRC measures have seen some success in enhancing the disciplinary functions of the stock market.

More broadly, these findings are consistent with the agency literature, especially the hypothesis developed and tested in the "law and finance" approach to corporate governance that weak protection for outside investors leads to poor corporate governance (La Porta, Lopez-deSilanes, and Shleifer 1999, and La Porta et al. 2000). In particular, the presence of a large controlling shareholder is found to strengthen the link of CEO turnover to firm performance, while the lack of independent directors and the presence of a CEO who simultaneously holds a position in the controlling shareholder firm are both found to weaken the link. ${ }^{8}$ These findings provide support for the hypothesis that the second type of agency problem is particularly acute where investor protection is weak. ${ }^{9}$ In China, where explicit protection for private property rights was not instituted in the Constitution until 1999, one would not expect the conflict between the controlling shareholder and minority outside shareholders to be resolved easily.

\footnotetext{
${ }^{7}$ This finding is consistent with previous literature showing that SOE reforms without privatization do not help firm performance. See Shirley and Xu (2001), for instance, for a study on the effects of performance contracts. For a discussion on the costs from delaying the privatization process in China, see for example Lardy (1998). For specific studies suggesting the importance of ownership reform in China, see, for instance, Chang, McCall, and Wang (2003), who find that Chinese township and village enterprises with better defined ownership have significantly better performance, and Zhang, Zhang, and Zhao (2003) find that state ownership leads to lower R\&D and productive efficiency in industrial firms. In addition, Bai and et. al. (2000) explain the low profit incentives and poor performance in SOEs by the continued need for multitasking including employment provision, and findings in Bai and Xu (2005) suggest that the Chinese government may have non-financial objectives for SOEs.

${ }^{8}$ These findings are consistent with the results in Wang, Xu, and Zhu (2004), who find that the post-listing firm performance tends to be poor in China and the effects depend on the balance of power between top shareholders, which is potentially another proxy for the likelihood of large shareholders exploiting smaller shareholders.

${ }^{9}$ For empirical evidence from East Asian countries that supports this hypothesis, see Claessens, Djankov, and Lang (2000).
} 
In other words, the continuous difficulty faced by Chinese listed firms in solving the two types of principal-agent problems seems to be fundamentally a result of the weak protection provided by China's legal system to investors. Like many other developing countries, China does not have either a comprehensive set of legal rules that provide protection for outside investors or the ability to effectively implement existing laws that govern the operations of corporations and securities market. In addition, China's problem is further compounded by its socialist legacy. The state ownership of the majority of listed company stocks implies that the protection for even the largest investor, the state, is also weak due to the ambiguity of public property rights.

Consequently, any fundamental improvement in Chinese firms' ability to resolve the two types of principal-agent problems (or equivalently in their corporate governance) will require a broad program that encompasses not only privatization but also laws and their effective implementation to provide better protection for investors. ${ }^{10}$

The structure of the paper is as follows. In Section 2, we will present background information on the current Chinese corporate governance system and develop testable hypotheses. The data and empirical strategy are discussed in Section 3, followed by Section 4 where econometric specifications are laid out and the estimates presented. Section 5 concludes.

\section{Section 2: Background information and testable hypotheses}

This section provides background information on China's stock market and listed firms, and develops hypotheses to be tested in the paper.

\subsection{Two key features of China's stock market and main hypotheses}

${ }^{10} \mathrm{Wu}(2003)$ makes a similar argument. 
The first feature Chinese listed firms have in common is the highly concentrated ownership structure. On average, the proportion of company stock owned by the largest shareholder is more than $44 \%$, and over $42 \%$ of listed firms have a controlling shareholder owning more than half of the company stock. This degree of concentration is both a reflection of the state's reluctance to let go of its control of the former SOEs and a response of privately controlled firms to the weak protection for outside investors.

Concentration of both control and ownership of listed firms is prevalent in countries with weak protection for investors and is argued to be a rational response by private entrepreneurs to the lack of investor protection (La Porta et al. 2000). Among other reasons for choosing such concentration, a larger stake in the company gives the controlling shareholder more incentives to monitor the management and thus leads to higher performance-turnover sensitivities. It is worth pointing out that the same argument applies to listed firms controlled by all types of shareholders. Therefore, to the extent that the state cares about firm performance among other things, a higher concentration of state ownership presumably will also lead to more effective corporate governance measures such as a stronger link between firm performance and executive turnover. Our first main hypothesis, therefore, is: Hypothesis I: Sensitivities of CEO turnover to firm performance are higher for listed firms with greater proportion of the stock owned by the controlling shareholder. ${ }^{11}$

The above hypothesis applies to any country where investor protection is weak, be it China or Italy. Our second hypothesis, however, is unique to transitional economies like China, where the state ownership and control still loom large. The dominance of state ownership and control in China's listed firms is fundamentally due to the Chinese government's delay in privatization. Since their very beginning in the early 1990s, the stock exchanges in Shanghai and

\footnotetext{
${ }^{11}$ Volpin (2002) develops and tests a similar hypothesis using Italian data.
} 
Shenzhen were conceived and designed primarily to help SOEs raise capital and reduce debt burden, rather than serving as the channel for efficient resource allocation. To achieve the goal of raising funds for SOEs, until 2000 public listing has required quotas, which were reserved almost exclusively for SOEs. It is thus only natural that the vast majority of listed firms in China are spin-offs of SOEs.

Although the policy of "grasping the big and letting go of the small," adopted at the Chinese Communist Party's 15th Party Congress in 1997, vowed support for privatization of small SOEs and opened the door for ownership restructuring for large SOEs, the ownership restructuring of Chinese listed firms has been slow. ${ }^{12}$ In 2003, the government still remains the largest shareholder in over $80 \%$ of the listed firms, either directly by owning state shares or indirectly by owning legal person shares, which together constitute about two thirds of the company stock of all listed firms. ${ }^{13}$

For the reasons discussed below, the dominance of state ownership will have negative implications for meaningful SOE reform and the further development of China’s stock market.

${ }^{12}$ The Chinese government has long been delaying the privatization process in its enterprise reforms until very recently. In the 1970s and 1980s, Chinese SOE reform measures were mainly designed to align the interests of SOE management with the interests of the government, and they include the administrative decentralization and profit retention policies (fangquan rangli) in the late 1970s to the early 1980s; the changes in the forms of profit sharing and funding sources for SOEs during the mid to late 1980s (ligaishui and bogaidai); and the incentive contracts for managers and workers during the late 1980s (chengbaozhi). For a detailed discussion on China's earlier enterprise reform from a historic perspective, see Naughton (1995) and Yang (1997). Beginning in the early 1990s, increasingly bolder SOE reform measures were implemented. The Chinese Communist Party's (the CCP) $14^{\text {th }}$ Congress held in 1992 called for establishing a modern corporation system similar to the West spurred the stock market's rapid development in China since 1992. In contrast to the largely gradualist SOE reform measures adopted in the 1970s and 1980s, the CCP's $14^{\text {th }}$ Congress in October 1992 opened a new chapter in China's SOE reform by proposing more radical changes including corporate and ownership structure changes. Following the $14^{\text {th }}$ Congress, the National Peoples' Congress (NPC) and its Standing Committee passed the Corporate Law in 1993, which laid out the essential rules for corporate governance in modern Chinese corporations and provided blueprints for later SOE reforms. The major breakthrough in terms of ownership changes occurred in 1997, when the Chinese Communist Party's 15th Party Congress made the shareholding system a showpiece of China's enterprise reform and public listing a main mechanism to attain the goal for large SOEs, and this led to a rapid increase in the number of firms listed in the two stock exchanges in China. The growth of the stock market was further aided by the passage of the Securities Law in 1998. For China's delay in privatizing its SOEs, see Huang (2003). For a general discussion on enterprise reform in transition economies, see Megginson and Netter (2001).

${ }^{13}$ Unless noted otherwise, numbers cited in this paper are computed from the GTA and Sinofin data bases by the authors. For similar estimates for different types of share percentages, see, for instance, Qiang (2003). 
First, state ownership suffers from the separation between ownership by the general public and control by the bureaucrats in charge of the daily operations of the firm. Because the bureaucrats may have very different goals from the general public, there exists inherent conflict of interests between the owners and the management (Shleifer and Vishny 1997). Secondly, even if the state is able to hold the bureaucrats accountable for implementing its goals in operating the stateowned firms, the multiple and oftentimes conflicting social objectives pursued by the state imply that the firm's economic performance often has to be sacrificed to achieve other "higher" social goals such as full employment. Furthermore, the state and legal person shares of Chinese listed firms held directly or indirectly by the government are non-tradable shares and any transfer of these stocks has to be approved by numerous government agencies including both the CSRC and the Ministry of Finance. This greatly weakens the market’s disciplinary function through takeover since without the government's approval there is virtually no threat of an alternative management team that can offer a better return for the current firm's asset, no matter how unsatisfactory the firm's performance is.

All these facts lead to weak incentives for state owned firms to aggressively pursue profit maximization and increase the firm's market value. It is to be expected, therefore, that these firms will lack corporate governance measures that link firm performance with the fortune of the CEO. ${ }^{14}$ In particular, they will not have strong link between firm performance and CEO turnover.

In addition, most of the firms controlled by the government still follow the same routine as SOEs in their top personnel decisions. Depending on the management level of the SOE, the government of the corresponding level has the authority to appoint its top management. For

\footnotetext{
${ }^{14}$ For the negative impact on managerial incentives of these arrangements, see Bonin (1976), Weitzman (1976), Kornai (1992), Ickes and Samuelson (1987), Litwack (1991), and Dewatripont and Roland (1997).
} 
SOEs at the central government level, for example, the central government's CCP (Communist Party of China) Department of Organization has the final say in the selection of its CEO or the General Manager; for SOEs in the charge of provincial government, the Department of Organization at the provincial government calls the shots. ${ }^{15}$

For the listed firms that have the government or SOEs as their largest shareholders, the same procedures tend to apply. According to China’s Corporate Law, the personnel decisions are supposed to be made by the board of directors. However, in reality, the candidates for the Chairman of the board of directors and the General Manager are almost always nominated by the largest government shareholders and then rubber-stamped by the board. The multiplicity of the goals of the government thus implies that economic performance of the firm will often become secondary to political pressures and social connections in making personnel decisions. Thus, our second main hypothesis is:

Hypothesis II: Sensitivities of CEO turnover to firm performance are lower for listed firms still controlled by the state than for privately-controlled listed firms.

\subsection{Other hypotheses: the role of CSRC and "insider" control}

In addition to the two main features of China's stock market, we also consider three potentially important factors which may affect the quality of corporate governance in China: independent directors, insider CEOs, and ST-designation. The first and second factors speak to the prevalence of "insider" control and the severity of the second type of agency problem in Chinese listed firm. The third factor and the first are measures introduced by the CSRC to improve corporate governance in China.

\footnotetext{
${ }^{15}$ Our discussion on the personnel appointment process is largely based on the surveys and interviews conducted in Beijing, Shanghai, and Chengdu, Sichuan in the summer of 2004.
} 
First, in its effort to improve corporate governance in China, the biggest challenge faced by the CSRC is “insider” control. Although ownership concentration and the consequent “insider” control help reduce the principal-agent problem between owners and the management, particularly in countries with poor protection of outside investors, it also aggravates the conflict of interests between the controlling shareholder and the minority shareholders (La Porta, Lopezde-Silanes, and Shleifer, 1999). ${ }^{16}$ We develop two hypotheses concerning how well Chinese listed firms resolve the agency problem between the controlling shareholder and outside investors.

According to China's Corporate Law, the board of directors represents the interests of all the shareholders. But in reality, the board of directors in Chinese listed firms is often staffed with individuals that are directly or indirectly affiliated with the controlling shareholder, leaving small individual investors with no representation. ${ }^{17}$ An average listed firm in China has about ten members on its board of directors, among which only two are independent directors in 2002, the year when the percentage is the highest in our sample.

Under such circumstances, one way to protect the interests of minority shareholders is to guarantee a minimum number of independent directors on the board who are not affiliated with either the controlling shareholder or the listed firm, but rather serve on behalf of the outside investors. The recent effort to improve the quality of corporate governance in China has followed this logic and the CSRC has introduced certain standard corporate governance measures borrowed from the West. ${ }^{18}$ Notably, according to the “Guidelines for Establishing Independent

${ }^{16}$ See also Bebchuk (1999) and Bebchuk, Kraakman, and Triantis (1999).

${ }^{17}$ See Qiang (2003) and Wu (2003) for discussions on "insider” control in Chinese listed firms.

${ }^{18}$ Following the Asian Crisis, a number of corporate governance reform measures were imposed on many crisis-hit Asian countries, such as South Korea, Indonesia, Thailand and Malaysia. All these countries now require a minimum percentage of independent outside directors on the board. See Nam and Nam (2004) for more detailed description of these corporate governance reform measures. 
Director System in Listed Firms” issued by the CSRC on August, $16^{\text {th }}, 2001$, each listed firm in China would be required to have at least two "independent directors" on its board of directors by June $30^{\text {th }}$, 2002, and by June $30^{\text {th }}, 2003$, at least one third of the board members would be required to be "independent directors." 19 The CSRC also states in the "Guidelines" and the “Corporate Governance Model Codes” that the board of directors should establish committees in charge of compensation, auditing, and nomination. In addition, at least half of the members serving on these committees should be independent directors and the chairs of these committees should also be served by independent directors. ${ }^{20}$

Given the prevalence of “insider” control in Chinese listed firms, independent directors who are truly independent of the controlling shareholders have the potential to substantially improve the quality of corporate governance. There exist, however, conflicting views on how effective independent directors are in improving corporate governance in China. According to recent newspaper coverage, increasingly independent directors have hired independent auditors to audit the books for the listed firm, while others have refused to acquiesce to decisions made by

\footnotetext{
${ }^{19}$ According to the Guidelines, an individual need to meet the following conditions to be considered "independent": (i) Neither the individual nor his or her relatives (including spouses, parents, children, siblings, parents in law, sons and daughters in law, spouses of siblings, and siblings of spouses) work for the listed firm or its subsidiaries; (ii) the individual does not directly or indirectly own more than $1 \%$ of the stock of the listed firm; (iii) neither the individual nor his or her close relatives (including spouses, parents and children) are among the largest 10 shareholders of the listed firm; (iv) neither the individual or his or her close relatives work for a company that owns more than $5 \%$ of the stock of the listed firm; and (v) neither the individual nor his or her close relatives work for one of the largest 5 shareholder companies.

${ }^{20}$ Another example of the reform measures is the separation of the CEO position from the board chairmanship. Though there is no clear stipulation in the Company Law or other laws in China, many Chinese scholars and policy makers have recommended the separation as a good corporate governance practice See, for instance, He (2004). Mr. Jiancheng He is the chair of SASAC’s (State Asset Supervision and Administration Commission) supervisory board in charge of the largest SOEs. Since the majority of board members and management are both appointed by the largest shareholders, however, the board of directors is not truly independent of management in most listed firms in China, and the artificial separation of CEO and chairman may not be sufficient to achieve the real independence of the board. As expected, we find no discernable effect on turnoverperformance sensitivities of the separation of the CEO position from the board chairmanship (in contrast, Goyal and Park, 2002 find evidence on the beneficial effect of the separation of the CEO position from the board chairmanship for the U.S.). These and other unreported results are available from the corresponding author at tkato@mail.colgate.edu upon request.
} 
the management and the controlling shareholders of the listed firm. ${ }^{21}$ On the other hand, independent directors till recently only had very limited rights in litigation, predicting low effectiveness in their presence. Both views, however, are based on anecdotal evidence, and we will provide rigorous econometric evidence on their validity. Our next hypothesis is, therefore: Hypothesis III: The appointment of independent directors enhances turnover-performance sensitivities. $^{22}$

Another manifestation of the prevalence of "insider" control is the close relationship the list firm's top management has with its controlling shareholder company. Between 1998 and 2002, CEOs of 41\% of China's listed firms simultaneously held executive positions in the controlling shareholder companies. ${ }^{23}$ Furthermore, our data indicate that the high percentage of "insider" CEOs applies to both listed firms controlled by the state as well as those controlled by private firms or private individuals.

Since appointing one of its own executives to be the listed firm's CEO is the most direct way for the controlling shareholder to exert its control, the CEO is probably expected to serve the interests of the controlling shareholder firm more so than those of the listed firm. It follows that for CEOs holding executive positions in the controlling shareholder firms, the criteria for measuring the CEO’s success may thus be linked more to his or her effectiveness in helping to enhancing the interests of the controlling shareholder rather than to his or her ability in improving performance of the listed firm per se. For private controlling shareholders, the temptation clearly exists to steal wealth from their controlled listed firms. Even for state

\footnotetext{
${ }^{21}$ See, for instance, “Are Independent Directors Useful?” the Economic Observer (Jingji Guancha), June 26, 2004 edition and "How can Independent Directors Become Truly Independent?" the Liberation Daily (Jiefang Ribao), December 20, 2004 edition.

${ }^{22}$ See for example, Weisbach (1988), Dahya, McConnell, and Travlos (2002), and Suchard, Singh, and Barr (2001) which test a similar hypothesis for listed firms in the U.S., the U.K. and Australia.

${ }^{23}$ See Table 1.
} 
controlled listed firms, since the state has multiple goals in operating a firm, including providing social welfare and political stability, it has the incentive to transfer wealth from its controlled listed firm to help achieve these goals.

To the extent that such wealth transfer activities, i.e., "tunneling” activities, are more prevalent in firms in which CEOs pledge allegiance to the controlling shareholder and that the amount of "tunneling" is reflected negatively in the listed firm's performance, the link of CEO turnover to firm performance is expected to be weaker for these listed firms. ${ }^{24}$ Our next hypothesis is therefore a story about the Chinese version of "management entrenchment”: Hypothesis IV: CEO turnover-performance sensitivities are weaker for listed firms with CEOs who also hold positions in the controlling shareholders. ${ }^{25}$

Finally, we study the effectiveness of a listing suspension measure adopted by the CSRC to improve corporate governance. In 1998, the CSRC introduced the ST designation policy to the Chinese stock market. Under the CSRC guidelines, a firm may become an ST firm for a variety of reasons such as experiencing net loss for two consecutive years or failing to keep the shareholders' equity above the registered capital. In general the CSRC uses the ST designation to warn firms with serious financial difficulties or certain abnormalities, because these troubles usually put investors' interest at stake. Following the ST designation, the firms will be forced out of the stock market (i.e. "de-listed”) if their performance does not improve in two years. Meanwhile, the ST firms will receive more strict scrutiny from regulators. Facing such pressing risk of delisting, the ST firms usually have a strong incentive to reform so that they can improve

\footnotetext{
${ }^{24}$ Several high-profile cases investigated by the CSRC since 2001 suggest that the most commonly used method of "tunneling" by controlling shareholders of Chinese listed firms is to borrow loans or secure loan guarantees from their controlled listed firms. (See various issues of Shanghai Securities (Shanghai Zhengquanbao).)

${ }^{25}$ Volpin (2002) develops and tests a similar hypothesis, using Italian data.
} 
their performance and rid themselves of ST labels. To achieve such goals, these firms will presumably strengthen the incentives faced by their CEOs. ${ }^{26}$

Hence, our last hypothesis is:

Hypothesis V: The ST designation will result in stronger performance-turnover ties for the STdesignated firms.

\section{Section 3: Data and Measurement}

\subsection{Defining CEOs and CEO turnover in Chinese Firms}

Many studies on executive turnover in the U.S. and other developed countries have focused on CEOs. ${ }^{27}$ In China, however, CEO is a relatively new concept and only very recently some companies have started to use the title. Since Chinese firms have historically used "General Manager (zongjinli)” as the title for their top executives, one is tempted to focus on these General Managers. However, a few facts complicate the matter and suggest that the designation of “General Manager” as the top executive in China may not be always correct. First, the Corporate Law in China stipulates that the Chairman of the board of directors is the legal person representative of a listed firm (Corporate Law §3, 1993). Second, the Chairman of the board of directors is appointed by the largest shareholder in the majority of listed firms in China. ${ }^{28}$ Given the highly concentrated ownership structure of Chinese listed firms, the Chairman appointed by the largest shareholder tends to be powerful and is often involved in the company's daily decision-making even without holding the position of “General Manager” simultaneously.

According to a survey of firms listed on the Shanghai Stock Exchange in 2001, about $80 \%$ of listed firms have the Chairmanship held by someone different from the General Manager

\footnotetext{
${ }^{26}$ See Bai et al. (2003) for more details on the ST-designation mechanism.

${ }^{27}$ See for example Murphy (1999) for a review of the literature on executive turnover.

${ }^{28}$ See for instance Wu (2003).
} 
and among these Chairmen, more than half receive salaries from the listed firm, work for the firm full time, and are generally involved in the company's daily decision making. Furthermore, it is commonly believed that when both the Chairman and the General Manager are responsible for a company’s daily operations, the Chairman is more powerful than the General Manager. ${ }^{29}$

Therefore, we adopt the following procedures to determine the top executive of the firm, referred to as CEO hereafter. When the same individual serves as both the Chairman and the General Manager, he or she is considered the CEO of the firm. When two separate individuals hold the Chairman and the General Manager positions, we consider the Chairman as the CEO insofar as he/she is paid by the listed firm. As discussed before, generally the Chairman is involved and has a final say in day to day management decision except when he or she is not paid by the listed firm but rather paid by the largest shareholder of the listed firm. One may argue, however, that it is plausible that the Chairman is involved in day to day business decision and still more powerful than the General Manager even if he is not paid by the listed firm, and that including those firms with CEOs identified somewhat ambiguously contaminate the results. Reassuringly our key results do not change qualitatively even if we limit our analysis to only those firms with CEOs defined clearly with little controversy (or firms with the same individuals serving both the Chairmanship and the General Manager position and with the Chairmen on the listed firm’s payroll).

Information on the General Manager and Chairman as well as accounting and financial data are obtained from the China Stock Market and Accounting Research Database (CSMAR) developed by Shenzhen GTA Information Technology Company, while data on ownership structure and corporate governance are assembled from the database developed by Sinofin

\footnotetext{
${ }^{29}$ See, for instance, “Chairman of the board or general manager: Who's the CEO in a Chinese company?” China Securities, Jan. 31, 2002. This was also confirmed during our interviews with Chinese executives in Beijing, Shanghai, and Chengdu in the summer of 2004.
} 
Information Services. The CSMAR data set has been used in previous studies, ${ }^{30}$ yet on our reading of the literature, we are the first to use the Sinofin dataset in academic research. Data are available annually for 1998 through $2002 .^{31}$

Using the CSMAR database, we first identify for each listed firm in each year whether the General Manager position and the Chairmanship are served by the same individual. For those firms with the same individual serving the General Manager position as well as the Chairmanship, we consider him/her the CEO. For the remainder, we use the CSMAR database to find out whether the Chairman is on the firm's payroll. If that is the case, we determine him/her the CEO. Otherwise we consider the General Manager (who is almost always on the firm’s payroll) the CEO. In the few cases where payroll information is not available in the database, we search online sources for information on who is in charge of the company's daily operations (for instance, who is cited as the most powerful figure by the major newspapers). When everything else fails, we rely on information from the previous and the following years to determine what position corresponds to CEO in a company.

The CSMAR database provides data on the starting year of each CEO's current term, with a typical term for CEOs being three years in China, but fails to supply the year in which he or she is first appointed to the CEO position. To obtain data on the total CEO tenure for those who serve more than a term from the CSMAR database, we supplement the CSMAR database with the annual reports of all listed firms.

The unit of observation in our analysis is the firm-year pair. We exclude from our analysis observations with CEOs who have not served for at least a full year at the CEO position, because the data only allow for annual performance measures and there is no meaningful annual

\footnotetext{
${ }^{30}$ See, for instance, Sun and Tong (2003), Bai, et. al (2003), and Bai, Liu, and Song (2003).

31 There is a companion paper in which we use the Sinofin dataset to examine executive compensation in Chinese listed firms (Kato and Long, 2004).
} 
performance measure to be linked to turnover probability of such CEOs with less than one year of experience.

Finally, to focus on CEO departures that are related to firm performance, we follow the standard approach used in the literature to exclude CEO departures due to death, illness or company control changes as missing values. ${ }^{32}$ Since the data do not allow us to identify CEO departures due to normal retirement, again following the literature we include CEO’s age to control for the impact on CEO departures of normal retirement. ${ }^{33}$

After applying the above exclusion criteria to the data, we end up with 638 firms and a total of 2181 observations over the period of 1999-2002. ${ }^{34}$ The summary statistics are given in Panel A of Table 1 . As shown in the table, in $17 \%$ of the observations, the Chairmanship and the General Manager position are held by the same individuals; the chairmen in $45 \%$ of the observations are paid by the listed firms and thus we refer them as the CEOs of their firms; and the remaining 38\% of the observations have the General Managers as their CEOs. On average, the CEOs working in Chinese listed firms look very similar to Chinese CEOs in general. CEOs in Chinese listed firms are on average 50 years old, and only $4 \%$ of them are female, very similar to findings on Chinese CEOs in general..$^{35}$ Their average tenure length is 2.3 years, much shorter than the average tenure of Chinese CEOs in general. ${ }^{36}$ This is, however, hardly surprising,

\footnotetext{
${ }^{32}$ See, for instance, Kaplan (1994) and Denis, Denis and Sarin (1997). One might argue that company control changes such as takeover may be caused by poor performance and thus should be considered. As in the case of prior studies, the data are not rich enough to distinguish such company control changes caused by poor firm performance from other changes.

${ }^{33}$ In addition, we assign missing values to observations where CEOs departing their CEO positions yet still remaining on board of the directors since such departures may well be normal retirement.

${ }^{34}$ Since we use lagged values in our subsequent regression analysis, our final sample time period is 19992002 rather than $1998-2002$.

${ }^{35}$ According to "Report on Chinese Entrepreneurs: Emergence and Development”(Zhongguo qiyejia chengzhang yu fazhan baogao), p27, by the Survey System for Chinese Entrepreneurs 2004, the average age of Chinese CEOs is 48 and the percentage of female CEOs is $4 \%$ in 2002.

${ }^{36}$ The Survey on Chinese entrepreneurs reports that in 1998 the percentages of CEOs with tenure length between 1 and 5 years, between 6 and 10 years, between 11 and 15 years, between 16 and 20 years, and more than 20 years, to be $36 \%, 28.3 \%, 26.7 \%, 6.4 \%$, and $2.6 \%$, respectively. In the same survey conducted in 2000 , the
} 
considering the short history of Chinese listed firms. ${ }^{37}$ Compared to CEOs of listed firms in the U.S. and Japan, CEOs of Chinese listed firms are much younger and have shorter tenure, although the tenure for Chinese CEOs in general is similar to, if not longer than, that in the U.S. and Japan. $^{38}$

The average annual CEO turnover rate is $24 \%$, substantially higher than the average CEO turnover rate reported for the U.S. and Japan (Kaplan 1994). Beginning in 2001, the CSRC requires all listed firms to disclose whether the CEO of the listed firm also holds executive positions in the controlling shareholder. For 2001 and 2002, over 41\% of them simultaneously hold positions in the controlling shareholders, suggesting close relationship between the listed firm and its controlling shareholder.

\subsection{Characteristics of Chinese Listed Firms}

For ownership structure, we will separate the listed firms into state controlled firms and non-state controlled firms, using data on whether the "ultimate controller" of the listed firm is the state. The ownership structure data are collected by Sinofin, and with one exception, the definition of the "ultimate controller" is comparable to that used in the corporate governance literature at $10 \%$ threshold level. ${ }^{39}$ The definition of the "ultimate controller" used in prior studies requires the firms in the middle layer of a control pyramid also be listed. But according to Liu, Sun, and Liu (2003), the main mechanism of indirect control for Chinese listed firms is

entrepreneurs reported an average of 1.6 turnovers for the top executives working in their firms during the previous 10 year period.

${ }^{37}$ Data on educational attainment are unfortunately extremely limited and available only for a very small subsample of 89 observations. For the small subsample, we find that $71 \%$ of firms with CEOs having at least a bachelor's degree, a substantially higher percentage than that reported for Chinese CEOs in general (4\%). The result, however, might be due to the very small sample size of selected individuals who report such information.

${ }^{38}$ See for instance Kato and Rockel (1992) and Kaplan (1994) and the above footnote.

39 See La Porta, Lopez-de-Silanes, and Shleifer (1999), Claessens, Djankov, and Lang (2000), and Faccio and Lang (2002). 
through a pyramid scheme where the largest shareholder of the listed firm is an unlisted firm or organization controlled by the state. One major limitation of the Sinofin database is that it only provides information on the ownership type of the ultimate controller (state or others) but not the actual percentage of shares owned by the ultimate shareholder directly and indirectly. ${ }^{40}$

Part B in Table 1 reports descriptive statistics on the type of ultimate controller and other key firm characteristics, where all the value variables are expressed in 1995-constant RMBs. As shown in the table, a typical listed firm is much smaller than a typical firm listed on NYSE, with an average market value about 1/20 of the NYSE firms. Among all the listed firms, $83 \%$ have the government as the ultimate controller, $10 \%$ have a private individual or a private firm as the ultimate controller, while only about $1 \%$ are ultimately controlled by firms with foreign investment. ${ }^{41}$ Finally, the largest shareholder of a typical listed firm owns over $44 \%$ of total company stock and over $42 \%$ of all listed firms have the largest shareholder owning more than half of the company stock, suggesting a highly concentrated ownership structure in Chinese listed firms.

According to the Corporate Law passed in 1993, all listed firms are required to have a board of directors, and the average size of the board of directors has remained around 10 between 1998 and 2002. But it was not until late 2001 did the CSRC issue the Guidelines for the Use of Independent Directors in Listed Firms, stipulating that there should be at least two independent members on each listed firm’s board of directors by June 30, 2002 and that independent directors should further constitute at least one third of the total number of directors

\footnotetext{
40 To the best of our knowledge, this is the only publicly available data on the "ultimate controller" of Chinese listed firms. Liu and Sun (2005) traced the chain of control for 1105 listed firms and calculated the shareholdings for their ultimate controllers and thus have the best data on ownership structure. However, their ownership structure information goes only till 2001 and their data are yet to be made available publicly.

${ }^{41}$ The remaining $6 \%$ are mostly owned by collective enterprises, non-profit organizations, or employee stock holding committees.
} 
by June 20, 2003. The guidelines proved very effective, rapidly raising the percentage of listed firms with independent directors from $2.5 \%$ at the end of 2000, to $6 \%$ in late 2001, and further to $31 \%$ by the end of 2002. The median number of independent directors reached above 2 by the end of 2002. Because the introduction of independent directors is largely an exogenous event imposed by the CSRC, our estimates on how the introduction of independent directors affects the quality of corporate governance will be less subject to endogeneity bias.

Finally, we define two concepts related to ST-designation to facilitate the study of how the designation affects a firm's performance-turnover relationship. ST-firms are defined as those firms that ever received ST-designation. Naturally, the proportion of ST-firms increased steadily over time, reaching 16 percent level at the beginning of 2002, as shown in the table. Among the ST-firms, we define a dummy variable, ST=1 if the firm has received the ST-designation by the beginning of the current year. The table shows that 35 percent of the observations (firm-year pairs) over 1999-2002 corresponding to the ST-firms with ST=1. In other words, for all STfirms, 65 percent of their yearly observations over 1999-2002 were pre-ST years and the remaining 35 percent were post-ST years.

\section{Section 4: Econometric Specifications and Results}

As is often done in the literature, we estimate CEO turnover-performance sensitivities by estimating a logit model. We begin with the standard benchmark model used in prior studies on Western firms:

(1) $\ln [\operatorname{Pr}($ TURNOVER $) / 1-\operatorname{Pr}($ TURNOVER $)]=\alpha+\beta$ PERFORMANCE $+\gamma Z+u$ where TURNOVER=1 if the firm replaces its CEO during the year, 0 otherwise; PERFORMANCE=firm performance in the previous year; $Z$ is a vector of control variables; $\alpha$ and $\beta$ are the coefficients of interest to be estimated; $\gamma$ is a vector of coefficients on the control 
variables; and $u$ is the disturbance term. For PERFORMANCE, as in the case of most prior studies, we use stock market performance measure (industry adjusted stock return or RETURN) as well as accounting measures. While nearly unanimous in the use of industry adjusted stock return as to measure stock performance, the literature is less uniform in the choice of accounting measures. Reflecting the somewhat less unanimous state of the literature, we consider four often used accounting measures: (i) industry adjusted Return on Asset or ROA; (ii) industry adjusted profit margin or MARGIN; (iii) annual change in ROA, or $\triangle \mathrm{ROA}$; and, (iv) annual change in MARGIN, or $\triangle$ MARGIN). ${ }^{42}$

In addition, the literature often considers firm performance from both the current period as well as the previous period. ${ }^{43}$ However, since $57 \%$ of the CEO departures in our sample occur in the first six months of the year, firm performance in the current year is likely to reflect the replacing CEO's job performance as much as it does the departing CEO's. Thus we use firm performance in the previous year. ${ }^{44}$

The control variables include a variety of dummy variables capturing the possible influence on CEO turnover of the CEO's age, gender, tenure as CEO, job title (general manager or chair/GM dual position), as well as firm size (measured by the logarithm of the firm's market value $^{45}$ and time effects. Specifically we created 11 dummy variables capturing the (non-linear) impact on CEO turnover of his/her age; and 10 dummy variables gauging the (non-linear) effects

\footnotetext{
42 See for example Kang and Shivdasani (1995), Denis, Denis, and Sarin (1997), Murphy (1999), Campbell and Keys (2002), and Anderson and Campbell (2004).

${ }^{43}$ See for instance, Kaplan (1994)

${ }^{44}$ We also consider firm performance in the previous two years in the regressions, which unfortunately leads to a substantial reduction in the sample size. In spite of the smaller sample size, however, reassuringly we find no discernable differences in our key results.

${ }^{45}$ We also use the number of employees as an alternative measure for firm size with similar results.
} 
on CEO turnover of his/her tenure as $\mathrm{CEO} .^{46}$ In addition, we also include dummy variables controlling for the possible impact on CEO turnover of our definitional differences in CEOs (i.e., whether the firm's CEO is identified as an individual serving both the General Manager position and the Chairmanship of the board; as an individual serving only the Chairmanship and on the firm's payroll; or as an individual serving only the General Manager position and on the firm's payroll.) To control for CEO's age and tenure is particularly important since we are unable to completely separate CEO turnover due to normal retirement from disciplinary turnover. ${ }^{47}$

Table 2 shows the maximum likelihood estimates of Equation (1). We find consistently for all specifications that the estimated coefficients on PERFORMANCE are negative (of the right sign) and statistically significant at least at the 10 percent level. To examine the magnitude of the estimated turnover-performance sensitivities, we use the estimated coefficients on PERFORMANCE and calculate the predicted change in the probabilities of CEO departure when PERFORMANCE improves from the $25^{\text {th }}$ percentile to $75^{\text {th }}$ percentile. Note that in calculating the predicted CEO turnover probability, we assign the median value for size and the mode values for all the other characteristics including the age, gender, tenure, and position type (dual, chair, or general manager) of its CEO. Turnover-performance sensitivities in China’s listed firms as a whole are rather modest. For example, an improvement of stock return from $25^{\text {th }}$ percentile to $75^{\text {th }}$ percentile will lead to a rather modest reduction in the turnover probability from 19 percent to 18 percent.

The rest of the estimated coefficients have predicted signs, although many are not statistically significant. Particularly noteworthy are the positive and statistically significant coefficients on Age (59-61) and Age ( $>=62)$, indicating that as compared to the omitted category

\footnotetext{
${ }^{46}$ Age (35-37)=1 if CEO is between 35 and 37, 0 otherwise; Age (38-41)=1 if CEO is between 38-41; and so on. Likewise, Tenure $1=1$ if tenure as CEO is one year; Tenure $2=1$ if tenure as CEO is two years; and so on.

${ }^{47}$ In addition, we also consider board size as an additional control and find no discernable differences.
} 
of Age (<35), CEOs over 59 years old are more likely to depart. Because mandatory retirement age in China is 60 for men (and 55 for women), these results confirm the importance of including age dummy variables to control for CEO turnover due to normal retirement. In addition, Table 2 shows that CEO turnover is less likely in larger firms (negative and significant estimated coefficients on SIZE).

Furthermore, CEO turnover is shown to be less likely for CEOs with Chairman/GM dual position as compared to CEOs with Chairman position only (the omitted category) and the difference in CEO turnover probability between the two types of CEOs is statistically significant at the 1 percent level. In addition, though not quite statistically significant, CEO turnover is shown to be more likely for CEOs with GM position only as compared to CEOs with Chairman position only. These findings are largely consistent with the notion that board members are less likely to make decisions involving their own dismissal. ${ }^{48}$

Finally, although none of the estimated coefficients on tenure dummy variables is statistically significant at the 10 percent level, it appears as if CEO turnover is more likely at the third and sixth year of tenure as CEO, which is consistent with the stipulation in the Corporate Law of China that the length of each term for the executive should not exceed three years, which seems to have served as the focal point for all listed firms (Chapter 2, Article 47 of the Corporate Law of China 1993).

We now study the main hypotheses outlined in Section 2. To mitigate potential endogeneity in studying how various factors affect performance-turnover relationship, firm characteristics such as ownership structure, board structure, ST-designation, as well as whether

\footnotetext{
${ }^{48}$ As explained in footnote 19, we also test whether turnover-performance sensitivities differ between CEOs with DUAL $=1$ and CEOs with DUAL $=0$ by adding an interaction term involving DUAL and PERFORMANCE and find no discernable effect on turnover-performance sensitivities. Similarly, we do not find significant effect of the GM position on turnover-performance sensitivities.
} 
its CEO is an insider CEO are measured in lagged values. To test Hypothesis I, we augment the benchmark model by SHARE (proportion of the stock owned by the largest shareholder) and an interaction term involving SHARE and PERFORMANCE:

(2) $\ln [\operatorname{Pr}($ TURNOVER $) / 1-\operatorname{Pr}($ TURNOVER $)]=\alpha+\beta_{1}$ PERFORMANCE $+\beta_{2}$ SHARE

$+\beta_{21}$ PERFORMANCE*SHARE $+\gamma Z+u$.

The estimated coefficient on the interaction term PERFORMANCE*SHARE will enable us to test Hypothesis I, or whether CEO turnover becomes more sensitive to firm performance as the controlling shareholder owns more share of the stock. ${ }^{49}$

Columns (1)-(5) of Table 3 present the maximum likelihood estimates of Equation (2). The estimated coefficients on PERFORMANCE*SHARE are always negative (of the right sign) and almost always statistically significant (except when $\Delta \mathrm{ROA}$ is used as a performance measure, it is not quite significant yet close to significant at the 10 percent level). This is consistent with the incentive hypothesis under weak investor protection, or Hypothesis I. When the largest shareholder of the listed firm has a greater stake in the firm, it will monitor the CEO more carefully and make his/her fate more tied to firm performance. ${ }^{50}$

To examine the magnitude of the effect on turnover-performance sensitivities of SHARE, we compare the predicted probabilities of CEO departure for the following two cases. The weak monitoring incentive case is the firm of which the largest shareholder owns $29.8 \%$ of company stock (the $25^{\text {th }}$ percentile of SHARE), while the strong monitoring incentive case is the firm with the largest shareholder owning $59.3 \%$ of company stock (the $75^{\text {th }}$ percentile of SHARE). As we did in the case of the benchmark model, we assign in both cases the median value of size and the

\footnotetext{
${ }^{49}$ We also try MAJORITY (=1 if the largest shareholder owns at least 50 percent of the stock, 0 otherwise) and find similar results.

${ }^{50}$ A similar result is obtained for Italy by Volpin (2002).
} 
mode value of all the other characteristics (including the age, gender, tenure, and position type (dual, chair, or general manager) of its CEO. An improvement of industry-adjusted stock return from the $25^{\text {th }}$ percentile to $75^{\text {th }}$ percentile will lead to a very modest improvement in the probability of CEO departure from 19 percent to 18 percent for the weak monitoring incentive case with SHARE $=25^{\text {th }}$ percentile. In stark contrast, for the strong monitoring incentive case with SHARE $=75^{\text {th }}$ percentile, the same stock return improvement will lower the CEO turnover rate from $21 \%$ to $17 \%$, a substantial change given that the average CEO turnover rate for the whole sample is $24 \%$. Similar results are obtained for all four accounting measures as well. In sum, our findings highlight the crucial role of controlling shareholder in China's listed firms, as expected for any economies with weak minority shareholders.

To test Hypothesis II, we further augment Equation (2), with PRIVATE and an interaction term involving PRIVATE and PERFORMANCE, where PRIVATE=1 if the firm's "ultimate controller" is a private individual or firm, 0 otherwise. Columns (6)-(10) in Table 2 present the logit estimates of such a further augmented turnover-performance model. First, insofar as economic performance is concerned, the estimated coefficient on PERFORMANCE*PRIVATE is negative (of the right sign) and statistically significant at the 5 percent level, confirming our hypothesis that there is a higher CEO turnover-performance sensitivity for listed firms with private individuals or firms as their ultimate controllers.

On the other hand, we find no statistically significant impact on turnover-performance sensitivities of PRIVATE when we substitute accounting measures for stock return (economic performance). A possible explanation is that listed firms with private individuals or firms as the 
ultimate controllers rely more on stock market performance than accounting performance which tends to be more subject to management manipulation, especially in China. ${ }^{51}$

Reassuringly our earlier results on the effect on turnover-performance sensitivities of SHARE have changed little even if we add PRIVATE and PERFORMANCE*PRIVATE, pointing to the robustness of our evidence for Hypothesis I.

Finally, the estimated coefficient on PRIVATE is positive and statistically significant at the 1 percent level consistently for all specifications. All things equal, CEO will enjoy less job security in listed firms with private individuals or firms as the ultimate controllers.

The magnitude of the effect of private control can be demonstrated by comparing four distinct cases. The two opposite extreme cases include: (i) the firm with strong incentive for the largest shareholder to monitor its CEO due to a relatively large stake in the firm (SHARE $=75^{\text {th }}$ percentile) and the ultimate controller of the firm is now private (PRIVATE=1); and (ii) the firm with weak incentive for the largest shareholder to monitor its CEO due to a relatively small stake in the firm (SHARE $=25^{\text {th }}$ percentile) and the ultimate controller of the firm is still the state (PRIVATE=0). And the two intermediate cases include: (iii) the firm with weak incentive for the largest shareholder to monitor its CEO due to a relatively small stake in the firm (SHARE $=25^{\text {th }}$ percentile) yet the ultimate controller of the firm is now private (PRIVATE=1); and (iv) the firm with strong incentive for the largest shareholder to monitor its CEO due to a relatively large stake in the firm (SHARE $=75^{\text {th }}$ percentile) yet the ultimate controller of the firm is still the state (PRIVATE=0). Again, all other firm characteristics are assigned the same values, at their median or mode values.

\footnotetext{
${ }^{51}$ See Guangyuan Wang, "Problems of the listed firms caused by defects in the listing system," China
} Economic Times (Zhongguo Jingji Shibao), March 13, 2002 edition. 
As expected, the case with SHARE $=75^{\text {th }}$ percentile and PRIVATE $=1$ displays the most substantial reduction in the probability of CEO turnover from 0.37 to 0.24 , following an improvement in stock performance from the $25^{\text {th }}$ percentile in the industry to the $75^{\text {th }}$ percentile. In addition, the opposite case with SHARE $=25^{\text {th }}$ percentile and PRIVATE $=0$ shows little reduction in the CEO turnover probability, following the same stock performance improvement. The two intermediate cases reveal a sensible pattern, i.e., a much greater reduction in the CEO turnover rate for the case with SHARE $=25^{\text {th }}$ percentile and PRIVATE $=1$ (from 0.32 to 0.24 , following a stock performance improvement from the $25^{\text {th }}$ percentile in the industry to the $75^{\text {th }}$ percentile) than for the case with SHARE $=75^{\text {th }}$ percentile and PRIVATE $=0$ (from 0.19 to 0.17 , following the same stock performance improvement). This potentially points to the importance of ownership change from the state to private (or privatization) in China's economic reform, although such results only hold for the stock performance measure. ${ }^{52}$

To test Hypothesis III and evaluate the effectiveness of a measure adopted by the CSRC to improve corporate governance in Chinese listed firms, or the introduction of independent members to their board of directors, we further augment our turnover-performance sensitivity model by INDEPENDENT and PERFORMANCE*INDEPENDENT where INDEPENDENT=the proportion of independent directors. Table 4 summarizes the results. This measure has been effective to the extent that performance-turnover relationship is a reasonable indicator for the quality of corporate governance. Specifically, the estimated coefficient on the interaction term involving PERFORMANCE and INDEPENDENT is negative and statistically significant at the 5 percent level when stock return is used and at the 10 percent level when MARGIN is used (when we use the other three accounting measures, the estimated coefficients

\footnotetext{
52 For the inefficacy of China's piecemeal approach to economic reform without privatization, see for example Lardy (1998).
} 
still have right sign yet not quite significant though fairly close to being significant at the 10 percent level). Overall, evidence tends to be consistent with Hypothesis III that independent directors will be conducive to strengthening CEO turnover-performance link. ${ }^{53}$

To illustrate the substantial magnitude of the impact on turnover-performance sensitivities of independent directors, we focus on a firm with the controlling shareholder being the state, which owns $37.4 \%$ of company stocks (the median level of SHARE). Using our logit estimates, we find that when there are no independent directors on the board of directors (INDEPENDENT=0), the change in firm performance leads to little change in the predicted probability of CEO turnover. When the proportion of independent directors is a third of the board members, however, the predicted turnover rate decreases considerably from $19 \%$ to $8 \%$, following a performance improvement from the $25^{\text {th }}$ percentile to the $75^{\text {th }}$ percentile of the industry-adjusted rate of return.

Finally, note that reassuringly our earlier results on SHARE and PRIVATE change little even if we consider INDEPENDENT, pointing to the robustness of our findings on the effects on turnover-performance sensitivities of SHARE and PRIVATE.

To exploit the panel nature of our data, we re-estimate the fully augmented model with SHARE, PRIVATE and INDEPENDENT, using random effects. Such random effect estimates are presented in Table 5. As the table confirms, we find no discernable difference between our earlier estimates and the estimates with random effects, pointing to the further robustness of our results.

\footnotetext{
${ }^{53}$ Since the percentage of independent directors increased over time, one concern with the observed significant effect of independent directors is that it merely reflects the corporate governance improvement over time. To take into account of this possibility, we estimate the model including interaction terms involving INDEPENDENT and year dummies. And reassuringly, we obtain very similar results.
} 
Testing the remaining two hypotheses, Hypotheses IV and V will require us to use substantial reduced samples, and hence we will revert to the most parsimonious specification, i.e., the benchmark model augmented with one additional variable and an interaction term involving the variable and PERFORMANCE at a time.

As discussed in Section 2.1, "insider" control is one of the biggest challenges in China's endeavor to improve its corporate governance, and insider-dominated boards of directors are a reflection of this phenomenon. This explains the utmost effort taken by the CSRC to increase the presence of independent directors and as shown above, the effort appears to be paying off. We now test Hypothesis IV to study another aspect of “insider" control, "insider” CEOs that simultaneously hold positions in the controlling shareholder company and the listed firm. Because information for "insider" CEOs is only available after 2000, unfortunately the sample size decreased substantially when studying this aspect of "insider" control.

The maximum likelihood estimates of the benchmark model, Eq. (1), augmented by INSIDER CEO (=1 if CEO also works for the controlling shareholder, 0 otherwise) and PERFORMANCE*INSIDER CEO are presented in Columns 1-5 in Table 6. As Column (1) demonstrates, we find a positive and statistically significant (at the 10 percent level) coefficient on PERFORMANCE* INSIDE CEO when we consider stock performance. As such, Hypothesis IV is supported insofar as stock performance is concerned. In other words, turnover-performance link is weaker when CEOs work for the largest shareholders. The results using accounting performance measures are unfortunately more mixed.

Again, we use the estimates to gauge the magnitude of the impact on turnoverperformance sensitivities of INSIDER CEO. A discernable reduction in the predicted CEO turnover rate following stock performance improvement from the $25^{\text {th }}$ percentile to $75^{\text {th }}$ 
percentile is obtained only for the case with the absence of "insider CEO" (from 24 percent to 18 percent). When insider CEOs are present, no such discernable drop in the predicted CEO turnover is found.

Finally, we test Hypothesis V by estimating the impact of ST-designation on turnoverperformance sensitivities. To avoid selectivity bias caused by unobserved heterogeneity between ST-designated firms and other firms, we use a sub-sample of ST-designated firms and estimate the benchmark model, Eq. (1) augmented with ST (=1 if the firm is given ST-designation by the beginning of the current year, 0 otherwise) and PERFORMANCE*ST. The sign and significance of the estimated coefficients on PERFORMANCE*ST will then indicate whether turnover-performance sensitivities change significantly after ST-designation.

Columns (6)-(10) of Table 6 present the logit estimates. When we use economic performance (or stock return), the estimated coefficient on PERFORMANCE*ST is negative and statistically significant at the 1 percent level. ST-designation will result in stronger turnoverstock performance sensitivity. On the other hand, no such impact of ST-designation on turnoverperformance sensitivities is found when accounting performance measures are used. ${ }^{54}$ The magnitude of the impact of ST-designation on turnover-performance sensitivities is found to be economically significant as well, with an improvement of industry-adjusted stock return from $25^{\text {th }}$ percentile to $75^{\text {th }}$ percentile resulting in a substantial drop in the predicted CEO turnover rate from 24 to 19 percent.

\footnotetext{
${ }^{54}$ We also try less parsimonious specifications by adding SHARE, PRIVATE, and INDEPENDENT and their interaction terms with PERFORMANCE, and find that the results on INSIDER CEO and ST are largely intact while as expected many estimated coefficients on SHARE, PRIVATE AND INDEPENDENT and their interaction terms are no longer significant.
} 


\section{Section 5: Concluding Remarks}

In this paper, we have studied the link between firm performance and CEO turnover using comprehensive financial and accounting data on China’s listed firms from 1999 to 2002, augmented by unique data on CEO turnover, ownership structure and board characteristics. Several patterns of the quality of corporate governance in China have emerged from our analysis. First, there is substantial variation in how closely Chinese listed firms link turnover of their CEOs to their firm performance. Second, the evidence as a whole suggests that a broad program including more comprehensive investor protection is needed to improve corporate governance in China and privatization may be an important part of the program.

Specifically, even if a firm is listed in China’s burgeoning stock markets, overall, CEO turnover-performance sensitivities are still not economically important (though statistically significant). However, the presence of a large controlling shareholder will enhance turnoverperformance sensitivities (and hence the quality of corporate governance). This is in support of the "law and finance" approach to corporate governance, which attributes inferior corporate governance to weak investor protection. Furthermore, consistent with the argument made in the transitional economy literature, privatization is found to raise turnover-stock performance sensitivities and thus improve corporate governance. Combining the above two findings implies that turnover-performance sensitivities are the greatest when a private firm or individual becomes a large controlling shareholder, at least when stock market performance is considered.

In terms of the CSRC's reform efforts to improve corporate governance in China, we have some encouraging news. Both the introduction of independent directors and the ST designation are found to boost the link between stock performance and CEO turnover and hence enhance the disciplinary functions of the stock market although we find little evidence on the 
favorable effect of CSRC's reform measures on the link of CEO turnover to accounting performance measures.

Finally, although China's labor market for executives is still in its early stage of development, there is evidence that executive turnover has served as an effective mechanism to infuse new blood into the firm's management and turn a company's poor performance around (Xu, Zhu, and Lin 2005). To further justify our focus on CEO turnover as a valid measure for the quality of corporate governance in China and hence ultimately the success of China's enterprise reform, we perform a simple mean-difference test of firm performance before and after CEO turnover. Table 7 presents the results. The data are based on paired-performance data of 293 listed firms, which experienced CEO turnover over the time period of 2000-2001. As shown in the table, all five performance measures have improved following CEO turnover and three of them are statistically significant at least at the 10 percent level. The improvement is also economically non-negligible (for example, industry adjusted stock return improves from 6 percent to 9 percent). CEO turnover appears to be an important barometer of the health of corporate governance of Chinese listed firms. 


\section{References}

Anderson, Christopher W. and Campbell, Terry L. "Corporate Governance of Japanese Banks." Journal of Corporate Finance, 2004, 10(3), pp. 327-54.

Bai, Chong-En and et. al. "A Multitask Theory of State Enterprise Reform." Journal of Comparative Economics, 2000, 28(4), pp. 716-38.

Bai, Chong-en; Liu, Qiao; Lu, Joe; Song, Frank M. and Zhang, Junxi. "Corporate Governance and Market Valuation in China," William Davidson Working Paper No. 564, 2003.

Bai, Chong-en; Liu, Qiao and Song, Frank M. "The Value of Private Benefits: Evidence from an Emerging Market for Corporate Control," Working Paper, University of Hong Kong, 2003.

Bai, Chong-En and Xu, Lixin Colin. "Incentives for CEOs with Multitasks: Evidence from Chinese State-Owned Enterprises." Journal of Comparative Economics, 2005, 33(3), pp. 517-39.

Bebchuk, Lucian Arye. "A Rent-Protection Theory of Corporate Ownership and Control," NBER Working Papers no.7203, National Bureau of Economic Research, 1999.

Bebchuk, Lucian; Kraakman, Reinier and Triantis, George. "Stock Pyramids, Cross-Ownership, and the Dual Class Equity: The Creation and Agency Costs of Separating Control from Cash Flow Rights," NBER Working Papers no. 6951, National Bureau of Economic Research, 1999.

Bonin, John P. "On the Design of Managerial Incentive Structures in a Decentralized Planning Environment." American Economic Review, 1976, 66(4), pp. 682-87.

Brunello, Giorgio; Graziano, Clara and Parigi, Bruno M. "CEO Turnover in Insider-Dominated Boards: The Italian Case." Journal of Banking and Finance, 2003, 27(6), pp. 1027-51.

Cai, Xiang and Chen, Chao. "Corporate Control, Restructuring, and Firm Performance in China." Chinese Economy,, 2004, pp. 67-86.

Campbell, Terry L., II and Keys, Phyllis Y. "Corporate Governance in South Korea: The Chaebol Experience." Journal of Corporate Finance: Contracting, Governance and Organization, 2002, 8(4), pp. 373-91.

Chang, Chun; McCall, Brian P. and Wang, Yijiang. "Incentive Contracting Versus Ownership Reforms: Evidence from China's Township and Village Enterprises." Journal of Comparative Economics, 2003, 31(3), pp. 414-28.

Claessens, Stijn and Djankov, Simeon. "Enterprise Performance and Management Turnover in the Czech Republic." European Economic Review, 1999, 43(4-6), pp. 1115-24.

. Manager Incentives and Turnover of Managers: Evidence from the Czech Republic. New York, London: St. Martin's Press, Macmillan Press, 2000.

Claessens, Stijn; Djankov, Simeon and Lang, Larry H. P. "The Separation of Ownership and Control in East Asian Corporations." Journal of Financial Economics, 2000, 58(1-2), pp. 81-112.

Dahya, Jay; McConnell, John J. and Travlos, Nickolaos G. "The Cadbury Committee, Corporate Performance, and Top Management Turnover." Journal of Finance, 2002, 57(1), pp. 461-83.

Defond, Mark L. and Hung, Mingyi. "Investor Protection and Corporate Governance: Evidence from Worldwide CEO Turnover." Journal of Accounting Research, 2004, 42(2), pp. 269-312.

Denis, David J.; Denis, Diane K. and Sarin, Atulya. "Ownership Structure and Top Executive Turnover." Journal of Financial Economics, 1997, 45(2), pp. 193-221.

Dewatripont, Mathias and Roland, Gerard. "Transition as a Process of Large-Scale Institutional Change," Advances in Economics and Econometrics: Theory and Applications: Seventh World Congress. Volume 2. Cambridge; New York and Melbourne: Cambridge University Press, 1997, 240-78.

Eriksson, Tor. "Managerial Pay and Executive Turnover in the Czech and Slovak Republics," the 2004 ASSA Meetings, San Diego, Jan. 3-5. 2004.

Faccio, Mara and Lang, Larry H. P. "The Ultimate Ownership of Western European Corporations." Journal of Financial Economics, 2002, 65(3), pp. 365-95.

Gibson, Michael S. "Is Corporate Governance Ineffective in Emerging Markets?" Journal of Financial and Quantitative Analysis, 2003, 38(1), pp. 231-50. 
Goyal, Vidhan K. and Park, Chul W. "Board Leadership Structure and CEO Turnover." Journal of Corporate Finance, 2002, 8(1), pp. 49-66.

Groves, Theodore; Hong, Yongmiao; McMillan, John and Naughton, Barry. "China's Evolving Managerial Labor Market." Journal of Political Economy, 1995, 103(4), pp. 873-92.

He, Jiachen. "Structure, Mechanisms, and Efficiency of Corporate Governance" (Gongsizhili Jiegou, Jizhi, Yu Xiaoluu)," Study Times (xuexi shibao). March 25, 2004.

Huang, Yasheng. Selling China: Foreign Direct Investment During the Reform Era. Cambridge; New York and Melbourne: Cambridge University Press, 2003.

Ickes, Barry W. and Samuelson, Larry. "Job Transfers and Incentives in Complex Organizations: Thwarting the Ratchet Effect." RAND Journal of Economics, 1987, 18(2), pp. 275-86.

Jefferson, Gary H.; Su Jian; Yuan, Jiang and Xinhua, Yu. "The Impact of Shareholding Reform on Chinese Enterprise, 1995-2001," William Davidson Institute Working Paper no. 542, University of Michigan, 2003.

Johnson, Simon; La Porta, Rafael; Lopez-de-Silanes, Florencio and Shleifer, Andrei. "Tunneling." American Economic Review, 2000, 90(2), pp. 22-27.

Kang, Jun-Koo and Shivdasani, Anil. "Firm Performance, Corporate Governance, and Top Executive Turnover in Japan." Journal of Financial Economics, 1995, 38(1), pp. 29-58.

Kaplan, Steven N. "Top Executive Rewards and Firm Performance: A Comparison of Japan and the United States." Journal of Political Economy, 1994, 102(3), pp. 510-46.

Kaplan, Steven N. and Minton, Bernadette A. "Appointments of Outsiders to Japanese Boards: Determinants and Implications for Managers." Journal of Financial Economics, 1994, 36(2), pp. 225-58.

Kato, Takao and Rockel, Mark. "Experiences, Credentials, and Compensation in the Japanese and U.S. Managerial Labor Markets: Evidence from New Micro Data." Journal of the Japanese and International Economies, 1992, 6(1), pp. 30-51.

Kato, Takao and Long, Cheryl. "Executive Compensation, Firm Performance, and State Ownership in China: Evidence from New Panel Data," William Davidson Institute Working Paper no.690 (revised in November 2004), University of Michigan, 2004.

Klapper, Leora F. and Love, Inessa. "Corporate Governance, Investor Protection and Performance in Emerging Markets," World Bank Policy Research Working Paper No. 2818 (forthcoming in Journal of Corporate Finance), March 2002.

Kornai, Janos. The Socialist System: The Political Economy of Communism. Princeton: Princeton University Press, 1992.

La Porta, Rafael; Lopez-de-Silanes, Florencio; Shleifer, Andrei and Vishny, Robert. "Investor Protection and Corporate Governance." Journal of Financial Economics, 2000, 58(1-2), pp. 3-27.

La Porta, Rafael; Lopez-de-Silanes, Florencio and Shleifer, Andrei. "Corporate Ownership around the World." Journal of Finance, 1999, 54(2), pp. 471-517.

Lardy, Nicholas R. China's Unfinished Economic Revolution. Washington, D.C.: Brookings Institution Press, 1998.

Lausten, Mette. "CEO Turnover, Firm Performance and Corporate Governance: Empirical Evidence on Danish Firms." International Journal of Industrial Organization, 2002, 20(3), pp. 391-414.

Litwack, John M. "Legality and Market Reform in Soviet-Type Economies." Journal of Economic Perspectives, 1991, 5(4), pp. 77-89.

Liu, Deqiang and Keijiro, Otsuka. "A Comparison of Management Incentives, Abilities, and Efficiency between SOEs and TVEs: The Case of the Iron and Steel Industry in China." forthcoming in Economic Development and Cultural Change, 2004.

Liu, Guy S. and Sun, Pei. "The Class of Shareholdings and Its Impacts on Corporate Performance: A Case of State Shareholding Composition in Chinese Public Corporations." Corporate Governance: An International Review, 2005, 13(1), pp. 46-59.

Liu, Shaojia; Sun, Pei and Liu, Naiquan. "Theory of Ultimate Ownership, Ownership Structure, and Firm Performance." Economic Research (Jingji Yanjiu), 2003, 4, pp. 51-62. 
Megginson, William L. and Netter, Jeffry M. "From State to Market: A Survey of Empirical Studies on Privatization." Journal of Economic Literature, 2001, 39(2), pp. 321-89.

Mengistae, Taye and Xu, Lixin Colin. "Agency Theory and Executive Compensation: The Case of Chinese State-Owned Enterprises." Journal of Labor Economics, 2004, 22(3), pp. 615-37.

Muravyev, Alexander. "Turnover of Senior Managers in Russian Privatised Firms." Comparative Economic Studies, 2003, 45(2), pp. 148-72.

Murphy, Kevin J. "Executive Compensation," Handbook of Labor Economics. Volume 3b. Amsterdam; New York and Oxford: Elsevier Science, North-Holland, 1999, 2485-563.

Nam, Sang-Woo and Nam, Il Chong. "Corporate Governance in Asia: Recent Evidence from Indonesia, Republic of Korea, Thailand and Malaysia," Unpublished manuscript, Asian Development Bank Institute, 2004.

Naughton, Barry. Growing out of the Plan: Chinese Economic Reform, 1978-1993. Cambridge University Press, 1995.

Neumann, Robert and Voetmann, Torben. "Top Executive Turnovers: Separating Decision and Control Rights." Managerial and Decision Economics, 2005, 26(1), pp. 25-37.

Pagano, Marco and Roell, Ailsa. "The Choice of Stock Ownership Structure: Agency Costs, Monitoring, and the Decision to Go Public." Quarterly Journal of Economics, 1998, 113(1), pp. 187-225.

Qiang, Qu. "Corporate Governance and State-Owned Shares in China Listed Companies." Journal of Asian Economics, 2003, 14(5), pp. 771-83.

Shirley, Mary M. and Xu, Lixin Colin. "Empirical Effects of Performance Contracts: Evidence from China." Journal of Law, Economics, and Organization, 2001, 17(1), pp. 168-200.

Shleifer, Andrei and Vishny, Robert W. "A Survey of Corporate Governance." Journal of Finance, 1997, 52(2), pp. 737-83.

Suchard, Jo-Ann; Singh, Manohar and Barr, Robert. "The Market Effects of CEO Turnover in Australian Firms." Pacific-Basin Finance Journal, 2001, 9(1), pp. 1-27.

Sun, Qian and Tong, Wilson H. S. "China Share Issue Privatization: The Extent of Its Success." Journal of Financial Economics, 2003, 70(2), pp. 183-222.

Volpin, Paolo F. "Governance with Poor Investor Protection: Evidence from Top Executive Turnover in Italy." Journal of Financial Economics, 2002, 64(1), pp. 61-90.

Wang, Xiaozu; Xu, Lixin Colin and Zhu, Tian. "State-Owned Enterprises Going Public: The Case of China." Economics of Transition, 2004, 12(3), pp. 467-87.

Weisbach, Michael S. "Outside Directors and CEO Turnover." Journal of Financial Economics, 1988, 20(1/2), pp. 431-60.

Weitzman, Martin L. "The New Soviet Incentive Model," Bell Journal of Economics. 1976, 251-57.

Wu, Jinglian (in Chinese). China Economic Reform (Zhongguo Jingji Gaige). Shanghai: Shanghai Yuandong Publishing, 2003.

Xu, Lixin Colin; Zhu, Tian and Lin, Yi-min. "Politician Control, Agency Problems and Ownership Reform: Evidence from China." Economics of Transition, 2005, 13(1), pp. 1-24.

Yang, Qixian. "SOE Reforms and Institutional Renovations," F. Dong, Y. Li and Z. Han, The Future Road of State Owned Enterprises. Beijing, P.R. China: Economic Science Publishing, 1997, 3052.

Zhou, Xianming. "CEO Pay, Firm Size, and Corporate Performance: Evidence from Canada." Canadian Journal of Economics, 2000, 33(1), pp. 213-51. 
Table 1 Summary Statistics (1999-2002)

\begin{tabular}{|c|c|c|c|c|}
\hline Variable & Mean & s.d. & Medium & $\mathrm{N}$ \\
\hline \multicolumn{5}{|l|}{ Part A: CEO characteristics } \\
\hline TURNOVER (=1 if CEO departs) & 0.24 & 0.43 & 0 & 2181 \\
\hline GENERAL(=1 if CEO is General Manager) & 0.38 & 0.47 & 0 & 2181 \\
\hline DUAL( $=1$ if CEO holds Chairman/GM dual position) & 0.17 & 0.37 & 0 & 2181 \\
\hline AGE & 49.62 & 7.81 & 50 & 2181 \\
\hline $\operatorname{FEMALE}(=1$ if CEO is female) & 0.04 & 0.19 & 0 & 2181 \\
\hline TENURE AS CEO & 2.34 & 1.39 & 2 & 2181 \\
\hline INSIDER CEO (=1 if CEO also works for the controlling shareholder) & 0.41 & 0.49 & 0 & 1039 \\
\hline \multicolumn{5}{|l|}{ Part B: Firm Characteristics } \\
\hline RETURN (industry-adjusted stock return) & 0.06 & 0.43 & -0.09 & 2181 \\
\hline Total asset & $1.78 \mathrm{E}+09$ & $2.45 \mathrm{E}+09$ & $1.13 \mathrm{E}+09$ & 2181 \\
\hline MCAP=Total market value of company stocks & $1.58 \mathrm{E}+09$ & $1.41 \mathrm{E}+09$ & $1.21 \mathrm{E}+09$ & 2181 \\
\hline Sales & $1.02 \mathrm{E}+09$ & $1.88 \mathrm{E}+09$ & $4.79 \mathrm{E}+08$ & 2181 \\
\hline Sales growth rate & 0.16 & 0.44 & 0.11 & 2181 \\
\hline ROA (industry-adjusted return on asset) & 0.02 & 0.22 & 0.04 & 2171 \\
\hline$\Delta \mathrm{ROA}$ (industry-adjusted change in return on asset) & -0.02 & 0.22 & -0.01 & 2171 \\
\hline MAR (industry-adjusted profit margin) & -0.18 & 4.25 & -0.01 & 2164 \\
\hline$\triangle$ MAR (industry-adjusted change in profit margin) & -0.13 & 3.25 & 0 & 2164 \\
\hline Proportion of firms controlled by the state ultimately & 0.83 & 0.37 & 1 & 2181 \\
\hline Proportion of firms controlled by private individuals or firms & 0.10 & 0.31 & 0 & 2181 \\
\hline Proportion of firms controlled by foreign individuals or firms & 0.01 & 0.11 & 0 & 2181 \\
\hline SHARE (controlling shareholder share) & 0.44 & 0.17 & 0.44 & 2181 \\
\hline MAJORITY (=1 if controlling shareholder shares exceeds 50\%) & 0.42 & 0.49 & 0 & 2181 \\
\hline Size of board of directors & 9.70 & 2.57 & 9 & 2181 \\
\hline Number of independent directors (1999-2002) & 0.83 & 1.18 & 0 & 2181 \\
\hline 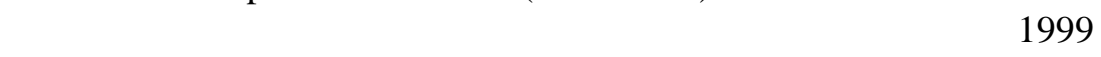 & 0.05 & 0.38 & 0 & 439 \\
\hline 2000 & 0.11 & 0.49 & 0 & 483 \\
\hline 2001 & 0.51 & 0.98 & 0 & 621 \\
\hline 2002 & 2.24 & 0.80 & 0 & 638 \\
\hline INDEPENDENT=proportion of independent directors (1999-2002) & 0.09 & 0.12 & 0 & 2181 \\
\hline Proportion of ST-firms 1999 & 0.02 & 0.19 & 0 & 439 \\
\hline Proportion of ST-firms & 0.07 & 0.27 & 0 & 483 \\
\hline Proportion of ST-firms & 0.10 & 0.33 & 0 & 621 \\
\hline Proportion of ST-firms & 0.16 & 0.37 & 0 & 638 \\
\hline $\begin{array}{l}\text { Among all ST-firms (1999-2002), } \\
\text { ST(=1 if firm i is an ST-firm in the current year) }\end{array}$ & 0.35 & 0.48 & 0 & 276 \\
\hline
\end{tabular}

Sources: Data on CEOs as well as accounting and financial data are from the China Stock Market and Accounting Research Database (CSMAR) developed by Shenzhen GTA Information Technology Company. Data on ownership structure and corporate governance are from the database developed by Sinofin Information Services.

Note: While the data for 1998 are also available, we use lagged values in our subsequent regression analysis and therefore our final sample time period is 1999-2002. All value variables are measured in RMB and adjusted for inflation using CPI (1995=100). 
Table 2: Turnover-performance sensitivities: the benchmark model (Logit estimation)

\begin{tabular}{|c|c|c|c|c|c|}
\hline & $(1)$ & $(2)$ & (3) & $(4)$ & (5) \\
\hline & $\begin{array}{l}\text { Using economic } \\
\text { performance } \\
\text { measure }\end{array}$ & \multicolumn{4}{|c|}{ Using accounting performance measures } \\
\hline & \multicolumn{5}{|c|}{ PERFORMANCE = } \\
\hline & RETURN & ROA & MAR & $\triangle \mathrm{ROA}$ & $\triangle \mathrm{MAR}$ \\
\hline PERFORMANCE & $\begin{array}{l}-0.368 \\
(0.190)+\end{array}$ & $\begin{array}{l}-3.853 \\
(0.741)^{* *}\end{array}$ & $\begin{array}{l}-0.672 \\
(0.197)^{* *}\end{array}$ & $\begin{array}{l}-0.962 \\
(0.578)+\end{array}$ & $\begin{array}{l}-0.563 \\
(0.222)^{*}\end{array}$ \\
\hline SIZE(=lnMCAP) & $\begin{array}{l}-0.209 \\
(0.070)^{* *}\end{array}$ & $\begin{array}{l}-0.158 \\
(0.068) *\end{array}$ & $\begin{array}{l}-0.157 \\
(0.068) *\end{array}$ & $\begin{array}{l}-0.183 \\
(0.069) * *\end{array}$ & $\begin{array}{l}-0.168 \\
(0.069) *\end{array}$ \\
\hline DUAL & -0.469 & -0.486 & -0.485 & -0.464 & -0.497 \\
\hline & $(0.179)^{* *}$ & $(0.180)^{* *}$ & $(0.180)^{* *}$ & $(0.178)^{* *}$ & $(0.181)^{* *}$ \\
\hline GENERAL & 0.119 & 0.170 & 0.132 & 0.105 & 0.114 \\
\hline & $(0.113)$ & $(0.115)$ & $(0.115)$ & $(0.113)$ & $(0.114)$ \\
\hline FEMALE & $\begin{array}{l}-0.372 \\
(0.300)\end{array}$ & $\begin{array}{l}-0.342 \\
(0.309)\end{array}$ & $\begin{array}{l}-0.476 \\
(0.329)\end{array}$ & $\begin{array}{l}-0.367 \\
(0.299)\end{array}$ & $\begin{array}{l}-0.463 \\
(0.317)\end{array}$ \\
\hline Age (35-37) & $\begin{array}{l}0.065 \\
(0.380)\end{array}$ & $\begin{array}{l}-0.005 \\
(0.392)\end{array}$ & $\begin{array}{l}0.020 \\
(0.382)\end{array}$ & $\begin{array}{l}0.017 \\
(0.378)\end{array}$ & $\begin{array}{l}0.035 \\
(0.379)\end{array}$ \\
\hline Age (38-40) & $\begin{array}{l}-0.141 \\
(0.348)\end{array}$ & $\begin{array}{l}-0.226 \\
(0.359)\end{array}$ & $\begin{array}{l}-0.267 \\
(0.354)\end{array}$ & $\begin{array}{l}-0.159 \\
(0.349)\end{array}$ & $\begin{array}{l}-0.243 \\
(0.352)\end{array}$ \\
\hline Age (41-43) & $\begin{array}{l}0.461 \\
(0.350) \\
\end{array}$ & $\begin{array}{l}0.366 \\
(0.363) \\
\end{array}$ & $\begin{array}{l}0.399 \\
(0.352) \\
\end{array}$ & $\begin{array}{l}0.459 \\
(0.347) \\
\end{array}$ & $\begin{array}{l}0.428 \\
(0.348)\end{array}$ \\
\hline Age (44-46) & $\begin{array}{l}0.046 \\
(0.335)\end{array}$ & $\begin{array}{l}-0.070 \\
(0.350)\end{array}$ & $\begin{array}{l}-0.068 \\
(0.340) \\
\end{array}$ & $\begin{array}{l}0.020 \\
(0.334)\end{array}$ & $\begin{array}{l}-0.026 \\
(0.335)\end{array}$ \\
\hline Age (47-49) & $\begin{array}{l}-0.197 \\
(0.327)\end{array}$ & $\begin{array}{l}-0.358 \\
(0.340) \\
\end{array}$ & $\begin{array}{l}-0.330 \\
(0.331)\end{array}$ & $\begin{array}{l}-0.222 \\
(0.326)\end{array}$ & $\begin{array}{l}-0.288 \\
(0.329) \\
\end{array}$ \\
\hline Age (50-52) & $\begin{array}{l}0.196 \\
(0.329) \\
\end{array}$ & $\begin{array}{l}0.079 \\
(0.343)\end{array}$ & $\begin{array}{l}0.088 \\
(0.333) \\
\end{array}$ & $\begin{array}{l}0.142 \\
(0.330)\end{array}$ & $\begin{array}{l}0.092 \\
(0.331) \\
\end{array}$ \\
\hline Age (53-55) & $\begin{array}{l}0.566 \\
(0.331)\end{array}$ & $\begin{array}{l}0.419 \\
(0.345)\end{array}$ & $\begin{array}{l}0.450 \\
(0.334)\end{array}$ & $\begin{array}{l}0.534 \\
(0.330)\end{array}$ & $\begin{array}{l}0.487 \\
(0.331)\end{array}$ \\
\hline Age (56-58) & $\begin{array}{l}0.252 \\
(0.336) \\
\end{array}$ & $\begin{array}{l}0.142 \\
(0.348) \\
\end{array}$ & $\begin{array}{l}0.168 \\
(0.338) \\
\end{array}$ & $\begin{array}{l}0.226 \\
(0.335) \\
\end{array}$ & $\begin{array}{l}0.206 \\
(0.335) \\
\end{array}$ \\
\hline Age (59-61) & $\begin{array}{l}0.763 \\
(0.340)^{*}\end{array}$ & $\begin{array}{l}0.637 \\
(0.351)\end{array}$ & $\begin{array}{l}0.665 \\
(0.342)\end{array}$ & $\begin{array}{l}0.735 \\
(0.338)^{*}\end{array}$ & $\begin{array}{l}0.691 \\
(0.339)^{*}\end{array}$ \\
\hline Age $(>=62)$ & $\begin{array}{l}1.224 \\
(0.361)^{* *}\end{array}$ & $\begin{array}{l}1.168 \\
(0.372)^{* *}\end{array}$ & $\begin{array}{l}1.154 \\
(0.362)^{* *}\end{array}$ & $\begin{array}{l}1.222 \\
(0.359)^{* *}\end{array}$ & $\begin{array}{l}1.172 \\
(0.359)^{* *}\end{array}$ \\
\hline Tenure1 & $\begin{array}{l}1.141 \\
(1.113)\end{array}$ & $\begin{array}{l}1.091 \\
(1.120)\end{array}$ & $\begin{array}{l}1.167 \\
(1.142) \\
\end{array}$ & $\begin{array}{l}1.112 \\
(1.111)\end{array}$ & $\begin{array}{l}1.193 \\
(1.132)\end{array}$ \\
\hline Tenure2 & $\begin{array}{l}0.896 \\
(1.120)\end{array}$ & $\begin{array}{l}0.895 \\
(1.126)\end{array}$ & $\begin{array}{l}0.937 \\
(1.148)\end{array}$ & $\begin{array}{l}0.860 \\
(1.117)\end{array}$ & $\begin{array}{l}0.928 \\
(1.138)\end{array}$ \\
\hline Tenure3 & $\begin{array}{l}1.797 \\
(1.119) \\
\end{array}$ & $\begin{array}{l}1.845 \\
(1.126) \\
\end{array}$ & $\begin{array}{l}1.897 \\
(1.148) \\
\end{array}$ & $\begin{array}{l}1.775 \\
(1.117)\end{array}$ & $\begin{array}{l}1.885 \\
(1.138)\end{array}$ \\
\hline Tenure4 & $\begin{array}{l}-0.251 \\
(1.140)\end{array}$ & $\begin{array}{l}-0.183 \\
(1.145)\end{array}$ & $\begin{array}{l}-0.156 \\
(1.167)\end{array}$ & $\begin{array}{l}-0.313 \\
(1.137)\end{array}$ & $\begin{array}{l}-0.175 \\
(1.157)\end{array}$ \\
\hline Tenure5 & $\begin{array}{l}-0.088 \\
(1.161) \\
\end{array}$ & $\begin{array}{l}-0.067 \\
(1.170)\end{array}$ & $\begin{array}{l}0.005 \\
(1.193) \\
\end{array}$ & $\begin{array}{l}-0.118 \\
(1.161) \\
\end{array}$ & $\begin{array}{l}-0.001 \\
(1.184)\end{array}$ \\
\hline Tenure6 & $\begin{array}{l}1.432 \\
(1.160)\end{array}$ & $\begin{array}{l}1.430 \\
(1.164)\end{array}$ & $\begin{array}{l}1.476 \\
(1.185)\end{array}$ & $\begin{array}{l}1.390 \\
(1.157)\end{array}$ & $\begin{array}{l}1.491 \\
(1.176)\end{array}$ \\
\hline Tenure7 & 0.695 & 0.696 & 0.782 & 0.716 & 0.799 \\
\hline
\end{tabular}




\begin{tabular}{|l|l|l|l|l|l|} 
& $(1.359)$ & $(1.372)$ & $(1.392)$ & $(1.368)$ & $(1.382)$ \\
\hline Tenure8 & -0.295 & -0.308 & -0.170 & -0.284 & -0.149 \\
& $(1.540)$ & $(1.537)$ & $(1.566)$ & $(1.551)$ & $(1.570)$ \\
\hline Tenure9 & 0.771 & 0.884 & 0.936 & 0.729 & 0.848 \\
& $(1.560)$ & $(1.533)$ & $(1.562)$ & $(1.559)$ & $(1.561)$ \\
\hline Observations & 2181 & 2171 & 2164 & 2171 & 2164 \\
\hline
\end{tabular}

Sources: Data on CEOs as well as accounting and financial data are from the China Stock Market and Accounting Research Database (CSMAR) developed by Shenzhen GTA Information Technology Company. Data on ownership structure and corporate governance are from the database developed by Sinofin Information Services.

Note: The data are based on a pooled cross-sectional time series dataset of 634 listed firms over the time period of 1999-2002. All value variables are measured in RMB and adjusted for inflation using CPI (1995=100). All models include various dummy variables capturing the possible influences on CEO turnover of the CEO's job title (general manager, or chair/GM dual position and time effects. Robust standard errors (in parentheses) control for correlation and clustering at firm level.

+ significant at $10 \%$; $*$ significant at $5 \%$; ** significant at $1 \%$ 
Table 3: Ownership structure and turnover-performance sensitivities (Logit estimation)

\begin{tabular}{|c|c|c|c|c|c|c|c|c|c|c|}
\hline & $(1)$ & $(2)$ & (3) & $(4)$ & (5) & (6) & $(7)$ & $(8)$ & (9) & $(10)$ \\
\hline & $\begin{array}{l}\text { Using } \\
\text { economic } \\
\text { performance } \\
\text { measure }\end{array}$ & \multicolumn{4}{|c|}{ Using accounting performance measures } & $\begin{array}{l}\text { Using } \\
\text { economic } \\
\text { performan } \\
\text { ce } \\
\text { measure } \\
\end{array}$ & \multicolumn{4}{|c|}{ Using accounting performance measures } \\
\hline & \multicolumn{10}{|c|}{ PERFORMANCE= } \\
\hline & RETURN & ROA & MAR & $\triangle \mathrm{ROA}$ & $\triangle \mathrm{MAR}$ & RETURN & ROA & MAR & $\triangle \mathrm{ROA}$ & $\triangle \mathrm{MAR}$ \\
\hline PERFORMANCE & $\begin{array}{l}0.456 \\
(0.339) \\
\end{array}$ & $\begin{array}{l}-0.488 \\
(1.570) \\
\end{array}$ & $\begin{array}{l}0.520 \\
(0.412) \\
\end{array}$ & $\begin{array}{l}0.872 \\
(1.079)\end{array}$ & $\begin{array}{l}0.477 \\
(0.445) \\
\end{array}$ & $\begin{array}{l}0.807 \\
(0.355)^{*}\end{array}$ & $\begin{array}{l}-0.004 \\
(1.748) \\
\end{array}$ & $\begin{array}{l}0.510 \\
(0.417)\end{array}$ & $\begin{array}{l}0.216 \\
(1.359)\end{array}$ & $\begin{array}{l}0.214 \\
(0.454)\end{array}$ \\
\hline $\begin{array}{l}\text { PERFORMANCE } \\
\text { *SHARE }\end{array}$ & $\begin{array}{l}-2.083 \\
(0.830)^{*}\end{array}$ & $\begin{array}{l}-8.884 \\
(3.590)^{*}\end{array}$ & $\begin{array}{l}-3.166 \\
(0.941)^{* *}\end{array}$ & $\begin{array}{l}-6.385 \\
(4.133)\end{array}$ & $\begin{array}{l}-2.693 \\
(1.031)^{* *}\end{array}$ & $\begin{array}{l}-2.569 \\
(0.845) * *\end{array}$ & $\begin{array}{l}-9.664 \\
(3.788)^{*}\end{array}$ & $\begin{array}{l}-3.204 \\
(0.934) * *\end{array}$ & $\begin{array}{l}-6.352 \\
(4.847)\end{array}$ & $\begin{array}{l}-2.377 \\
(1.039) *\end{array}$ \\
\hline SHARE & $\begin{array}{l}0.213 \\
(0.301) \\
\end{array}$ & $\begin{array}{l}0.179 \\
(0.317) \\
\end{array}$ & $\begin{array}{l}0.159 \\
(0.308) \\
\end{array}$ & $\begin{array}{l}0.046 \\
(0.298)\end{array}$ & $\begin{array}{l}0.131 \\
(0.303) \\
\end{array}$ & $\begin{array}{l}0.366 \\
(0.306) \\
\end{array}$ & $\begin{array}{l}0.358 \\
(0.322) \\
\end{array}$ & $\begin{array}{l}0.348 \\
(0.313) \\
\end{array}$ & $\begin{array}{l}0.213 \\
(0.306)\end{array}$ & $\begin{array}{l}0.313 \\
(0.308) \\
\end{array}$ \\
\hline $\begin{array}{l}\text { PERFORMANCE } \\
\text { *PRIVATE }\end{array}$ & & & & & & $\begin{array}{l}-1.544 \\
(0.729) *\end{array}$ & $\begin{array}{l}-1.706 \\
(2.107) \\
\end{array}$ & $\begin{array}{l}-0.016 \\
(0.609) \\
\end{array}$ & $\begin{array}{l}1.547 \\
(1.042) \\
\end{array}$ & $\begin{array}{l}0.511 \\
(0.431)\end{array}$ \\
\hline PRIVATE & & & & & & $\begin{array}{l}0.707 \\
(0.205)^{* *}\end{array}$ & $\begin{array}{l}0.628 \\
(0.195)^{* *}\end{array}$ & $\begin{array}{l}0.625 \\
(0.198)^{* *}\end{array}$ & $\begin{array}{l}0.589 \\
(0.197)^{* *}\end{array}$ & $\begin{array}{l}0.595 \\
(0.199)^{* *}\end{array}$ \\
\hline Observations & 2181 & 2171 & 2164 & 2171 & 2164 & 2181 & 2171 & 2164 & 2171 & 2164 \\
\hline
\end{tabular}

Sources: Data on CEOs as well as accounting and financial data are from the China Stock Market and Accounting Research Database (CSMAR) developed by Shenzhen GTA Information Technology Company. Data on ownership structure and corporate governance are from the database developed by Sinofin Information Services.

Note: The data are based on a pooled cross-sectional time series dataset of 634 listed firms over the time period of 1999-2002. All value variables are measured in RMB and adjusted for inflation using CPI (1995=100). All models include various dummy variables capturing the possible

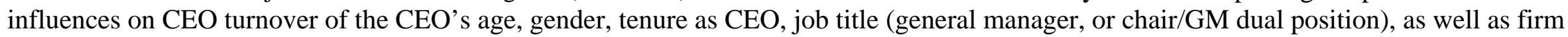
size (measured by the logarithm of the firm's market value) and time effects. Robust standard errors (in parentheses) control for correlation and clustering at firm level.

+ significant at 10\%; * significant at 5\%; ** significant at $1 \%$ 
Table 4 Independent directors and turnover-performance sensitivities: (Logit estimation)

\begin{tabular}{|c|c|c|c|c|c|}
\hline & (1) & $(2)$ & (3) & (4) & (5) \\
\hline & $\begin{array}{l}\text { Using } \\
\text { economic } \\
\text { performance } \\
\text { measure }\end{array}$ & \multicolumn{4}{|c|}{ Using accounting performance measures } \\
\hline & \multicolumn{5}{|c|}{ PERFORMANCE $=$} \\
\hline & RETURN & ROA & MAR & $\triangle \mathrm{ROA}$ & $\triangle \mathrm{MAR}$ \\
\hline PERFORMANCE & $\begin{array}{l}0.829 \\
(0.356)^{*}\end{array}$ & $\begin{array}{l}0.793 \\
(1.874)\end{array}$ & $\begin{array}{l}0.361 \\
(0.335)\end{array}$ & $\begin{array}{l}1.993 \\
(1.072)\end{array}$ & $\begin{array}{l}0.284 \\
(0.461)\end{array}$ \\
\hline $\begin{array}{l}\text { PERFORMANCE } \\
\text { *INDEPENDENT }\end{array}$ & $\begin{array}{l}-9.231 \\
(4.619)^{*}\end{array}$ & $\begin{array}{l}-15.044 \\
(11.354)\end{array}$ & $\begin{array}{l}-4.528 \\
(2.673) \\
\end{array}$ & $\begin{array}{l}-14.941 \\
(9.520) \\
\end{array}$ & $\begin{array}{l}-4.135 \\
(3.433) \\
\end{array}$ \\
\hline INDEPENDENT & $\begin{array}{l}-0.931 \\
(1.038) \\
\end{array}$ & $\begin{array}{l}-0.475 \\
(0.495) \\
\end{array}$ & $\begin{array}{l}-0.242 \\
(0.263)\end{array}$ & $\begin{array}{l}-0.098 \\
(0.222) \\
\end{array}$ & $\begin{array}{l}-0.036 \\
(0.199) \\
\end{array}$ \\
\hline $\begin{array}{l}\text { PERFORMANCE } \\
\text { *SHARE }\end{array}$ & $\begin{array}{l}-2.429 \\
(0.839) * *\end{array}$ & $\begin{array}{l}-10.605 \\
(3.890)^{* *}\end{array}$ & $\begin{array}{l}-2.703 \\
(0.883) * *\end{array}$ & $\begin{array}{l}-13.994 \\
(3.192)^{* *}\end{array}$ & $\begin{array}{l}-2.365 \\
(1.060)^{*}\end{array}$ \\
\hline SHARE & $\begin{array}{l}0.374 \\
(0.304)\end{array}$ & $\begin{array}{l}0.368 \\
(0.323)\end{array}$ & $\begin{array}{l}0.337 \\
(0.312)\end{array}$ & $\begin{array}{l}0.211 \\
(0.309)\end{array}$ & $\begin{array}{l}0.317 \\
(0.309) \\
\end{array}$ \\
\hline $\begin{array}{l}\text { PERFORMANCE } \\
\text { *PRIVATE }\end{array}$ & $\begin{array}{l}-1.494 \\
(0.730)^{*}\end{array}$ & $\begin{array}{l}-1.880 \\
(2.107)\end{array}$ & $\begin{array}{l}0.573 \\
(0.467)\end{array}$ & $\begin{array}{l}-0.787 \\
(1.629)\end{array}$ & $\begin{array}{l}0.526 \\
(0.418)\end{array}$ \\
\hline PRIVATE & $\begin{array}{l}0.718 \\
(0.205)^{* *}\end{array}$ & $\begin{array}{l}0.632 \\
(0.196)^{* *}\end{array}$ & $\begin{array}{l}0.604 \\
(0.198) * *\end{array}$ & $\begin{array}{l}0.626 \\
(0.199) * *\end{array}$ & $\begin{array}{l}0.588 \\
(0.198) * *\end{array}$ \\
\hline Observations & 2181 & 2171 & 2164 & 2171 & 2164 \\
\hline
\end{tabular}

Sources: Data on CEOs as well as accounting and financial data are from the China Stock Market and Accounting Research Database (CSMAR) developed by Shenzhen GTA Information Technology Company. Data on ownership structure and corporate governance are from the database developed by Sinofin Information Services.

Note: The data are based on a pooled cross-sectional time series dataset of 634 listed firms over the time period of 1999-2002. All value variables are measured in RMB and adjusted for inflation using CPI (1995=100). All models include various dummy variables capturing the possible influences on CEO turnover of the CEO's age, gender, tenure as CEO, job title (general manager, or chair/GM dual position), as well as firm size (measured by the logarithm of the firm's market value) and time effects. Robust standard errors (in parentheses) control for correlation and clustering at firm level.

+ significant at $10 \% ; *$ significant at $5 \%$; ** significant at $1 \%$ 
Table 5 Random effect estimation

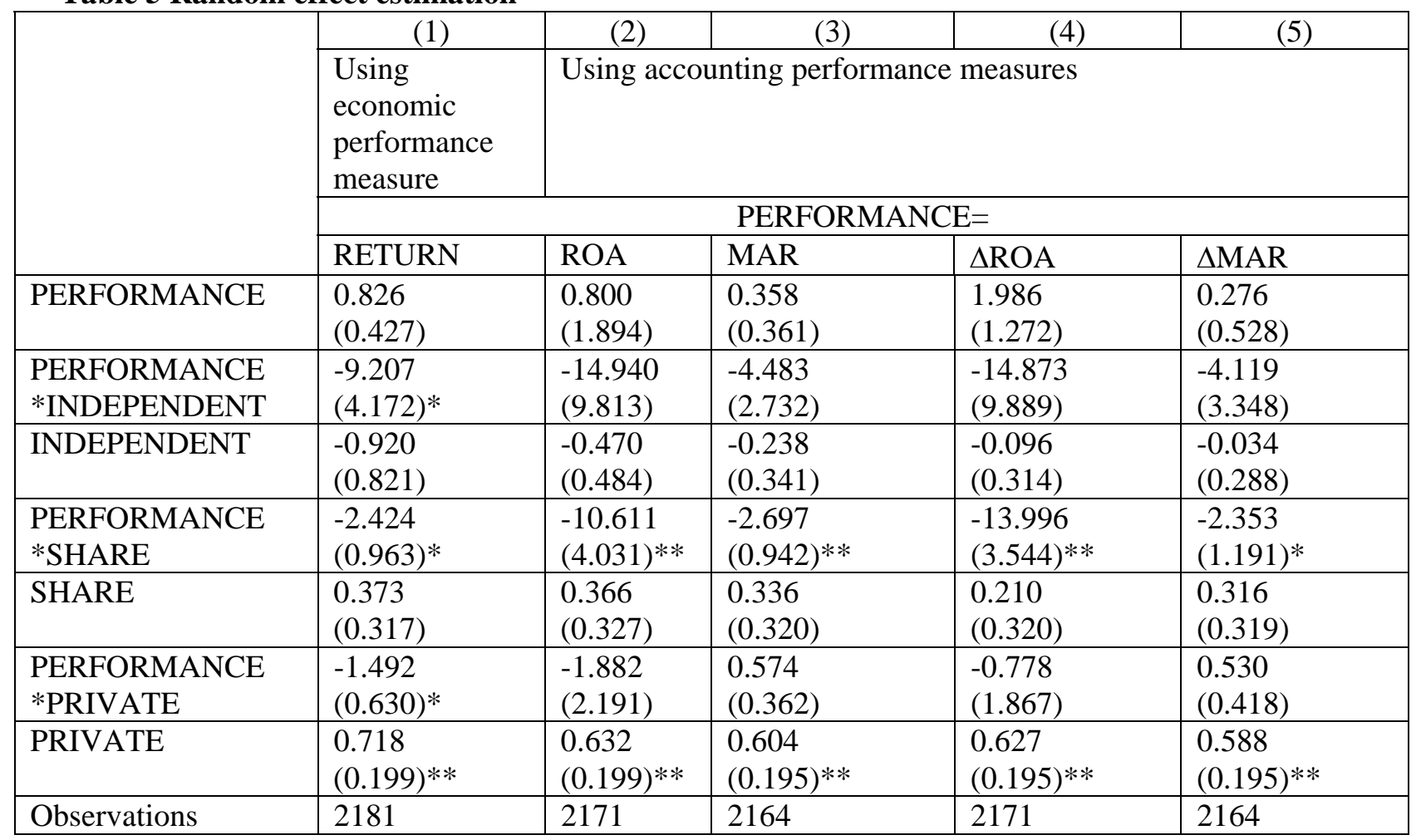

Sources: Data on CEOs as well as accounting and financial data are from the China Stock Market and Accounting Research Database (CSMAR) developed by Shenzhen GTA Information Technology Company. Data on ownership structure and corporate governance are from the database developed by Sinofin Information Services.

Note: The data are based on a pooled cross-sectional time series dataset of 634 listed firms over the time period of 1999-2002. All value variables are measured in RMB and adjusted for inflation using CPI (1995=100). All models include various dummy variables capturing the possible influences on CEO turnover of the CEO's age, gender, tenure as CEO, job title (general manager, or chair/GM dual position), as well as firm size (measured by the logarithm of the firm's market value), time effects and random effects. Asymptotic standard errors are reported in parentheses.

+ significant at $10 \%$; * significant at $5 \%$; ** significant at $1 \%$ 
Table 6: insider CEO, ST-designation, and turnover-performance sensitivities (Logit estimation)

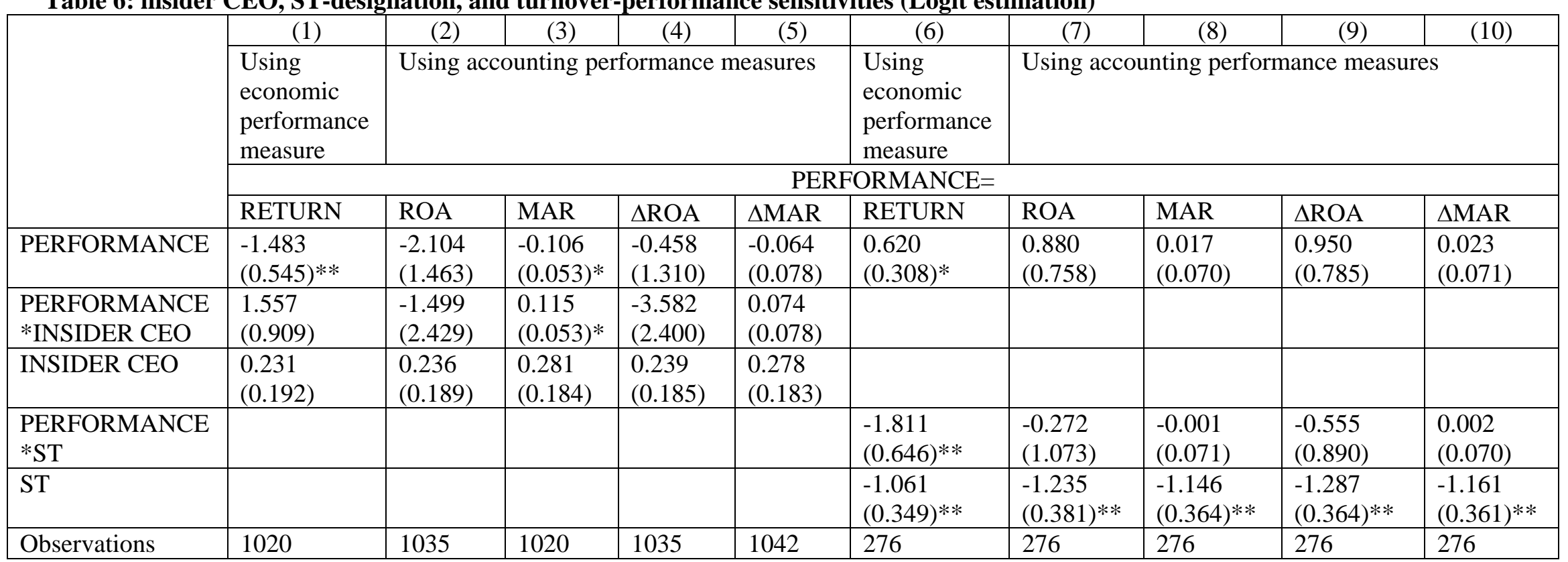

Sources: Data on CEOs as well as accounting and financial data are from the China Stock Market and Accounting Research Database (CSMAR) developed by Shenzhen GTA Information Technology Company. Data on ownership structure and corporate governance are from the database developed by Sinofin Information Services.

Note: For Specifications (1)-(5), since information for "insider" CEOs is only available since 2000, we were able to use only observations after 2000. For Specifications (6)-(10), we excluded all firms which did not receive ST-designation over the time period of 1999-2002. All value variables are measured in RMB and adjusted for inflation using CPI (1995=100). All models include various dummy variables capturing the possible influences on CEO turnover of the CEO's age, gender, tenure as CEO, job title (general manager, or chair/GM dual position), as well as firm size (measured by the logarithm of the firm's market value) and time effects. Robust standard errors (in parentheses) control for correlation and clustering at firm level.

+ significant at $10 \%$; significant at $5 \%$; ** significant at $1 \%$ 
Table 7: Firm performance before and after CEO turnover: Mean difference tests

\begin{tabular}{|l|l|l|l|}
\hline \multirow{2}{*}{ Performance measure } & \multicolumn{2}{|c|}{ Mean } & t-test \\
\cline { 2 - 3 } & $\begin{array}{l}\text { Year before CEO } \\
\text { turnover (N=293) }\end{array}$ & $\begin{array}{l}\text { Year after CEO } \\
\text { turnover (N=293) }\end{array}$ & \\
\hline RETURN & 0.055 & 0.091 & $-1.4033+$ \\
ROA & -0.018 & -0.015 & -0.4026 \\
MARGIN & -0.060 & -0.043 & -0.6570 \\
DROA & -0.013 & 0.025 & $-2.2774^{*}$ \\
MMAR & -0.066 & 0.157 & $-1.3035+$ \\
\hline \hline
\end{tabular}

Sources: Data on CEOs as well as accounting and financial data are from the China Stock Market and Accounting Research Database (CSMAR) developed by Shenzhen GTA Information Technology Company.

Note: The data are based on paired-performance data of 293 listed firms, which experienced CEO turnover over the time period of 2000-2001. Since all observations where the CEO has less than one year's tenure are excluded from our sample, each of these 293 firms experienced exactly one CEO turnover between 2000 and 2001.

+ significant at $10 \%$; * significant at $5 \%$; ** significant at $1 \%$ 